\title{
THE IMPACT OF LIBERALISATION AND GLOBALISATION ON INCOME INEQUALITY IN DEVELOPING AND TRANSITIONAL ECONOMIES
}

\author{
GIOVANNI ANDREA CORNIA
}

\author{
CESIFO WORKING PAPER NO. 843 \\ CATEgORY 5: Fiscal POLICY, MACROECONOMICS AND GROWTH \\ JANUARY 2003
}

Presented at CESifo CONFERENCE ON GLOBALISATION, INEQUALITY AND WELL-BEING, NOVEMBER 2002 


\title{
THE IMPACT OF LIBERALISATION AND GLOBALISATION ON INCOME INEQUALITY IN DEVELOPING AND TRANSITIONAL ECONOMIES
}

\begin{abstract}
This paper reviews changes in global, between-country and within-country inequality over 1980-2000 against the background of the shifts that occurred in this area during the globalisation of 1870-1914. The paper finds that recent changes in global and betweencountry inequality are not marked and depend in part on the conventions adopted for their measurement. In contrast, within-country inequality appears to have risen clearly in two thirds of the 73 countries analyzed mainly because of the policy drive towards domestic deregulation and external liberalisation. The paper concludes by analysing the differences between the inequality changes observed during 1980-2000 and 1870-1914.
\end{abstract}

JEL Classification: D31, F02.

\author{
Giovanni Andrea Cornia \\ University of Florence \\ Faculty of Economics \\ Via Curtatone 1 \\ 50123 Firenze \\ Italy \\ cornia@cce.unifi.it
}

The author gratefully acknowledges the financial support received from the International Policy Group of the ILO for the preparation of this paper. He also would like to thank François Bourguignon for sharing with him an unpublished draft of his 2001 paper with Christian Morisson. 


\title{
The impact of liberalisation and globalisation on income inequality in developing and transitional economies ${ }^{1}$
}

\author{
by \\ Giovanni Andrea Cornia ${ }^{\text {, }}$ \\ University of Florence
}

\section{INTRODUCTION}

Over the last two centuries, the world economy has become substantially more unequal. The last twenty years - the years of the second globalisation - have witnessed some slow down in this secular trend owing to the partial convergence of the incomes per capita of South East Asia, coastal China and part of urban India towards that of the advanced nations. They have also witnessed, however, an increase in the income gap between the advanced nations and all other developing and transitional countries, as well as a worrying reversal in many nations of past trends towards lower domestic inequality. While the debate on the causes of such changes is not over yet, initial evidence shows that they are in part due to the spread of the new 'global market paradigm'.

Such paradigm advocates the removal of barriers to international trade in goods and services, the opening up to foreign direct investments, the liberalisation of short-term portfolio flows, the creation of a standardised patent regime regulating technology transfers and intellectual property (now embodied in the TRIPS agreement of the WTO) and the simplification of all norms on travel, visa, payment systems and so on regulating international exchange. In contrast, liberalisation of the international labour flows remains off the policy agenda and since the early 1980s migration to Europe has slowed considerably due to the growing legal restrictions.

The globalisation of the world economy was preceded and made possible by the liberalisation of domestic markets that began in the early 1980s in many countries. For instance, the rise in foreign investments of the 1990s often consisted in the acquisition by multinational firms of state-owned enterprises and would not have taken place without their prior privatisation and the parallel liberalisation of the labour market that allowed large job cuts in privatised firms. Likewise, the surge in short-term portfolio flows of the 1990s would not have occurred without the liberalisation of the domestic financial markets during the 1980s. Thus, both theoretically and empirically, it is often impossible to separate the effects of globalisation from those of domestic liberalisation and we shall not try to do so in this paper.

The advocates of 'the global market paradigm' claim that this approach causes a reduction in domestic prices, offers major opportunities for export to the poor nations, channels world savings to countries with low capital accumulation but high rates of return on investment, accelerates the transfer of modern technology to backward countries and - as a result of all this - improves global economic efficiency. They also

\footnotetext{
1 The author gratefully aknowledges the financial support receied from the International Policy Group of the ILO for the preparation of this paper.

2 The author would like to thank Francois Bourguignon for sharing with him an unpublished draft of his 2001 paper with Christian Morisson.
} 
claim that liberalisation improves global income distribution thanks to the equalisation of factor prices across nations and the convergence of the income per capita of poorer countries with those of the advanced nations. While inequality may worsen in the advanced countries importing labour-intensive goods, it is expected to fall in the poor nations and on the global scale.

Against such background, the paper reviews the trends in global, between-country and within-country inequality over the last twenty years. To place such trends into historical perspective, the paper first analyses the changes in income concentration during the first wave of globalisation of 1870-1912 so as to emphasise similarities and differences observed over these two periods. The paper then shows that the predictions of the standard theory about the changes due to the liberalisation of the world economy often collide with a substantial and growing body of statistical evidence that shows that, over the last two decades, global inequality has risen and that past declines in within-country inequality have been reversed since the early 1980s. Finally, the paper explores the possible causes of these changes by emphasising in particular the linkages between liberalisation, globalisation and income distribution. Conclusions follow.

\section{GLOBAL INCOME DISTRIBUTION IN HISTORICAL PERSPECTIVE}

No doubt, the years 1870-1914 witnessed an unprecedented economic integration between the countries of the Old and New World. Thanks to a decline in transport costs and to cuts in the pre-1870 tariff rates, the ratio of exports plus imports to GDP rose steadily in all countries of the Old and New World 3 while commodity prices in the different markets converged sharply - with price gap cuts of 81 percent (Lindert and Williamson 2001). Meanwhile capital markets became much more integrated and international lending from Great Britain, France and Germany to the New World and a few Asian countries increased 20 times between the mid 1850s and 1914 (Anderson 1999). Finally, during this period, 60 million of mostly unskilled people migrated from the European periphery to the New World. The main impact of inequality of these changes is reviewed hereafter to help to put into perspective the impact of the current wave of globalisation.

To start with, a massive increase in migration and international trade among the nowdeveloped countries led to a substantial convergence in their average incomes per capita. The wage and income gap between the countries of the Old and New World were reduced markedly, as globalisation increased the relative demand for and the remuneration of the abundant factors and reduced that of the scarce factors (Williamson 1996, Andersen 1999). Mass migration from the periphery of Europe to the New World appears to explain most (some eighty- percent) of the drop in the New World-Old World wage gap between 1870 and 1914 (ibid.). Trade expansion accounted for another 30 percent while the capital flows from the comparatively poor Old World to the comparatively rich New World generated a modest disequalizing effect.

Second, globalisation caused a rise in within-country inequality in the rich countries of the New World and a fall in the poor Old World countries (Anderson 1999). In Great

\footnotetext{
3 The only exception was the US where the trade/GDP ratio remained constant over this period.
} 
Britain, Ireland and Sweden, the ratio of unskilled wages to farm rents per acre rose following a drop in the supply of unskilled labour due to migration and growing labour demand in the export-led manufacturing sector and to a fall in the prices of agricultural products due to cheap imports. The opposite effects obtained in the New World. Indeed, as predicted by the standard trade theory, free trade drove up the returns to land in the commodity-exporting New World and to labour in the manufactures-exporting Old World. Ceteris paribus, these changes had a disequalizing effect in the first region and an equalising effect in the second. Likewise, migration drove up unskilled wages and down the rental-wage ratio in the Old World but caused the opposite effect in the New World. In addition, as migrants were mostly unskilled, migration caused a reduction in the skilled-unskilled wage differential in the Old World but a rise in the same ratio in the New World. In turn, the flow of European investments to the New World partially offset the local fall in unskilled wages, as they moderated the decline in returns to a growing supply of unskilled labour, and so retarded the rise in wage inequality, while having the opposite effects in the Old World countries that exported capital.

Williamson (1996) suggests that such trends - the relative decline in the wages of unskilled workers in North America and the relative fall in the incomes of landowners in Europe - were at least partially responsible for the retreat from globalisation during the inter-war period. He warns that - as similar trends are re-emerging at the end of the $20^{\text {th }}$ century - the world may retreat again from its drive towards globalisation.

Third, convergence of real wages among the countries on the opposite sides of the North Atlantic was accompanied by a sharp divergence between the their wage rate and that of the colonial nations. As observed also over 1980-2000, the globalisation of 1870-1914 remained confined to a limited number of nations and did not manage to integrate into the world economy the now-developing countries. These were fully bypassed by the expansion of trade, capital and modern technology i.e. factors that promote growth and convergence, while migrants from these countries were kept out of the centre by restrictive migration policies and the high cost of the move. World labour markets were in fact as segmented then as they are today. The limited data on growth for countries such as India, China, Indonesia, Brazil, Mexico and Argentina confirm that - except for the latter country - these economies experienced much lower rates of growth and higher growth volatility than the now-developed countries (ibid.). The reasons for this divergence are not yet fully understood but have likely to do with domestic factors - such as lack of infrastructure and limited human capital - and international factors such as the global division of labour under colonial rule and asymmetric access to international markets.

Fourth, as a result of this growing divergence between the now-developed and the now-developing countries and of the mixed inequality changes within countries, global inequality rose steadily throughout the period 1870-1914 (Bourguignon and Morisson 2001).

\section{CHANGES IN GLOBAL AND BETWEEN COUNTRY INEQUALITY}

The global income distribution is the distribution of per capita income among the citizens of the world. It can be decomposed into the distribution of average income per capita between countries (the between-country distribution of income) and the 
distribution of income per capita within countries (the within-country distribution of income). Most studies on the global inequality suggest that between-country income differences explain 60-90 percent of the total income variation among the citizens of the world (depending on the inequality measure chosen) and that variations in the distribution of income within countries explain the remaining 10-40 percent ${ }^{4}$. Analyses of time trends in global inequality over the last twenty years can be grouped as follows:

- a first group of studies confines itself to the analysis of population-weighted changes in national-currency GDP or GNP per capita 5 converted into US dollars at the market exchange rates. Most of these studies underscore that while over the last 30 years several East Asian nations converged towards the average income per capita of the OECD group, the majority of the developing countries further diverged from it and so

\footnotetext{
${ }^{4}$ This was not true before the industrial revolution when most of global inequality was explained by within-country inequality (see the data for 1820 and 1870 in Table 2)

${ }^{5}$ Conclusions about the level of and changes in global inequality depend also on the approach adopted for its measurement and, in particular, on whether the comparisons:
}

- are carried out on the basis of GDP-GNP/capita (that is derived from the National Accounts) or disposable income per capita (that is derived from Household Income and Expenditure Surveys). The two concepts differ considerably. While both include imputations for incomes in kind, GNP/c also comprises undistributed profits and operating surpluses, the depreciation of capital stock, changes in inventories and public expenditure. As a result, estimates of income/c based on GDP/c are always substantially bigger (up to a factor of 3 ) than survey-based estimates. Thus estimates of global inequality are always much bigger (by up to 15-20 Gini points) when they are derived from GDP/c data. Finally, the ratio of income/c to GDP/c declines with the increase in GDP/c. Differences over time in inequality estimates based on the two concepts are thus not constant;

- make use of market exchange rates or of Purchasing Power Parity (PPP) exchange rates. It is well known that PPP exchange rates are higher. Thus, conversion of national incomes into US dollars by means of PPP exchange rates leads to a lower estimate of the income gap between developed and developing countries and to lower estimates of global inequality;

- on whether inter-national comparisons of GDP/c or income/c take into account the different population size of the countries compared with each other;

- implicitly assume that all citizens of one nation have the same income per capita or use synthetic statistics of the distribution of income (such as the Gini or Theil coefficients), or micro-data depicting in detail the distribution of income/c. The use of synthetic statistics of inequality is common in studies of global income inequality. But this approach does not provide a good approximation of the real distribution of household incomes/c. Indeed, the Gini coefficients are seldom computed on the basis of random samples or account for differences in household composition. In addition, they often rely on expenditure or consumption data, rather than income data, with the result that the shape of the income distribution and overall inequality are being artificially compressed. Evidence suggests that, survey-based Gini coefficients systematically understate the extent of inequality of the distribution of individual incomes in most countries;

- treat large 'highly dualistic' countries such as China and India as a single nation, two separate subnations (each comprised of the urban and the rural sector) or as multiple regions (as, for instance, in the case of China which is often separated in this kind of studies into its Inner, Middle and Coastal areas, i.e. regions that have grown at very different rates. Treating these different segments of a large economy as separate entities increases between-country inequality. 
contributed to a rise in global inequality. Results along these lines were obtained by an UNCTAD (1997) study on changes in the population-weighed distribution of average GDP per capita in current US dollars for 124 countries representing 93.6 of the world population. The study shows that the Gini coefficient of the global income distribution rose from 0.68 in 1980 to 0.74 in 1990 largely because of an increase in the income share of the countries with the richest 10 percent of the world population.

Similar conclusions were reached by the 1999 Human Development Report (UNDP 1999) which attributes this disequalizing trend to the rapid changes induced by globalisation. The Report analyses changes in the population-weighed distribution of GDP per capita converted into dollars at current exchange rates and finds that between-country inequality rose in recent years as the income gap between the fifth of the world's people living in the richest countries and the fifth living in the poorest ones rose from 30 to 1 in 1960 to 74 to 1 in 1997. The Gini coefficient consistent with these data rose from 0.71 in 1980 to 0.75 in 1995 (Dowrick and Akmal 2001).

These studies make use of market exchange rates to convert GDP/c in national currencies into US dollars and have been criticised because the 'traded sector bias' implicit in this approach raises the estimates of global inequality. Some authors (Schultz 1998) have shown, in fact, that between-country inequality is lower and may fall over time when national-currency GDP/c are converted into dollars by means of PPP exchange rates. Dowrick and Akmal (2001) note, however, that analyses based on PPP-exchange rates are themselves subject to another bias - the 'substitution bias, 6 - that lowers artificially the level of global inequality and its trend over time ${ }^{\text {. They }}$ therefore compute a new distribution of between-country income per capita making use of the Afriat true index and find that the Gini coefficient of such distribution rises slightly over time, from 0.615 in 1980 to 0.623 in 1993 . By adding a component for changes in within-country inequality, they obtain a Gini coefficient of the global income distribution that appears to have risen from 0.698 to 0.711 (equal to a moderate 1.7 percent increase) over the same period. Other inequality measures (Theil, the squared coefficient of variation and the variance of logs) however show bigger inequality increases of between 5 and 8.7 percent.

- A second - less numerous - group of studies is concerned with the distribution of income among individuals, so as to account for changes in income per capita both between and within countries. This is important, as even if between-country inequality rises (falls), world inequality may decline (increase) if within-country inequality falls (rises) in the large countries. Most of these analyses, however, do not make use of survey data, which alone can provide precise information on the shape of the income

\footnotetext{
6 In the PPP conversion method, the many services consumed by people in low-income countries are assigned US prices (which are much higher than those in developing countries). But, in developing countries, these services are consumed not because consumers are rich but because their local price is low. The GDP/c level obtained through the PPP method is thus inconsistent with the observed consumption structure and causes an artificial substitution in the consumption structure of low-income people.

The decline in inequality over time does not follow from differences between market and PPP exchange rates. The authors attribute it to the fact that country price structures between developing countries and the USA have become less and less similar over the last twenty years or so.
} 
distribution, but rely instead on synthetic inequality indexes (such as the Gini or Theil coefficients or quantile shares) and assumptions to estimate the shape of a country's income distribution (the most common being that all distributions are log-normal).

One of such studies by Korzeniewicz and Moran (1997) analysed changes in the world distribution of GNP per capita at current exchange rates in 46 nations accounting for 68 percent of the world population over the period 1965-92. They concluded that the world income distribution became more skewed, with the Gini index rising from 0.749 to 0.796 and the Theil index soaring from 1.15 to 1.32 . A decomposition of the latter index showed that between country inequality accounted respectively for 79 and 86 percent of the world inequality in 1965 and 1992, while within-country inequality declined proportionately. Similar results are arrived for the period 1960-89 by Schultz (1998) who used data on GDP per capita (converted at current exchange rates) for 120 countries. The Gini index rose steadily from 0.64 and 0.72 and the Theil index from 1.51 to 2.14. However, when converting GDP per capita at PPP-exchange rates, world inequality increased between 1960 and 1968 but declined between then and 1989. In the later period, convergence in inter-country income per capita more than offset the increase in within-country inequality. However, when China was excluded from the sample, the decline in global inequality after 1975 was no longer evident.

In turn, Stewart and Berry (n-d.) found that global inequality remained practically stable between 1980 and 1990. The global Gini coefficients, in fact, fell imperceptibly from 0.645 in 1980 to 0.638 in 1990. This outcome resulted from three offsetting trends: first, a decline in the gap in income per capita between the OECD countries and the fast growing and populous China, India and East Asia (Table 1); second, an increase in the income gap per capita between the OECD on the one side and low income Sub-Saharan Africa and middle-income Latin America, Eastern Europe and Middle East and North Africa on the other; and, third, the widening of within-country income inequality that affected many countries during those years (see section 4).

Table 1. Annual growth rate of GNP per capita: $1960-98$ and sub-periods

- World

- OECD

- East Asia except China

- China

- E.Europe and Central Asia

- Latin America

- Middle East \& North

Africa

- South Asia except India

- India

- Sub-Saharan Africa

$*$ The data in the various columns refer to the periods $1950-82$ and $1982-98, * *$ estimate
Source: The GNP per capita figures used for the computation of these results are in constant 1995

US dollars and are contained in cd-rom o World Development Indicators 2000.

Finally, Bourguignon and Morisson (2001) carried out a study of world income inequality over the years 1820 and 1992 on the basis of GDP per capita and quantile shares for 15 large countries and 18 aggregates of similar neighbouring nations. As for the last twenty years, the study points to a slow rise in inequality due to a moderate 
and unstable increase in between-country inequality, and to a rise of within-country inequality (Table 2). It is worth nothing that this study shows also that within-country inequality declined between 1950 and 1970 and then surged in the subsequent period - a finding confirmed also by the detailed review of the within-country inequality trends carried out in section 4 .

Table 2. Evolution of the global distribution of income and of the distribution of within- and between-country inequality, 1820-1972

\begin{tabular}{|l|l|l|l|l|l|l|l|l|}
\hline & 1820 & 1870 & 1910 & 1950 & 1960 & 1970 & 1980 & 1992 \\
\hline Gini Coefficient (global inequality) & 0.500 & 0.560 & 0.610 & 0.640 & 0.635 & 0.650 & 0.657 & 0.657 \\
\hline & & & & & & & & \\
\hline Theil Coefficient & & & & & & & & \\
\hline Inequality within country groups & 0.462 & 0.484 & 0.498 & 0.323 & 0.318 & 0.315 & 0.330 & 0.342 \\
\hline Inequality between country groups & 0.061 & 0.188 & 0.299 & 0.482 & 0.458 & 0.492 & 0.499 & 0.513 \\
\hline Total (global) inequality & 0.522 & 0.672 & 0.797 & 0.805 & 0.776 & 0.808 & 0.829 & 0.855 \\
\hline & & & & & & & & \\
\hline Mean logarithmic deviation & & & & & & & & \\
\hline Inequality within country groups & 0.370 & 0.382 & 0.399 & 0.303 & 0.300 & 0.304 & 0.321 & 0.332 \\
\hline Inequality between country groups & 0.053 & 0.162 & 0.269 & 0.472 & 0.466 & 0.518 & 0.528 & 0.495 \\
\hline Total (global) inequality & 0.422 & 0.544 & 0.668 & 0.775 & 0.766 & 0.823 & 0.850 & 0.827 \\
\hline
\end{tabular}

Source: Bourguignon and Morisson (2001)

Finally, Sala-i-Martin (2002) reconstructs the global income distribution by adding up the national income distributions of 125 countries for the period 1970-98. To do so, he estimates the yearly national income distribution for the period 1970-98 of 78 countries for which several datapoints on the income shares were available. For 29 nations with only one datapoint, he assumed that the income shares remained constant throughout 1970-98. Finally, for 28 countries with no information whatsoever, he assumed a perfectly egalitarian distribution over the entire period. These heroic assumptions allow him to estimate a Gaussian kernel density function for every year and country and - by adding up these individual density functions - to derive the global income distribution as well as the distribution of income between-countries and within-countries. The results in Table 3 show that between-country inequality rose modestly between 1970 and 1980 and declined since then, as the growth of China since 1978 and India in the 1990s was faster than that of the OECD countries. Meanwhile, within-country inequality rose steadily over the entire period, including because of the sharp rise in domestic inequality recorded in China, India and other large countries. As the increase in within-country inequality was smaller than that in between-country inequality, global inequality fell since 1980. Also in this case, removing China from the sample raises global inequality and reduces within-country inequality.

Table 3. Evolution of the global distribution of income and of the distribution

of within- and between-country inequality, 1970-98

\begin{tabular}{|l|l|l|l|l|l|}
\hline & 1970 & 1980 & 1990 & 1992 & 1998 \\
\hline Gini Coefficient (global inequality) & 0.633 & 0.638 & 0.630 & 0.621 & 0.609 \\
\hline & & & & & \\
\hline Theil Coefficient & & & & & \\
\hline Inequality within country groups & 0.186 & 0.193 & 0.194 & 0.195 & 0.203 \\
\hline Inequality between country groups & 0.586 & 0.593 & 0.583 & 0.554 & 0.513 \\
\hline
\end{tabular}




\begin{tabular}{|l|l|l|l|l|l|}
\hline Total (global) inequality & 0.771 & 0.786 & 0.776 & 0.749 & 0.716 \\
\hline & & & & & \\
\hline Mean logarithmic deviation & & & & & \\
\hline Inequality within country groups & 0.170 & 0.181 & 0.201 & 0.206 & 0.226 \\
\hline Inequality between country groups & 0.634 & 0.647 & 0.586 & 0.557 & 0.513 \\
\hline Total (global) inequality & 0.805 & 0.828 & 0.787 & 0.763 & 0.739 \\
\hline & & & & & \\
\hline Squared coefficient of variation & & & & & \\
\hline Inequality within country groups & 0.454 & 0.483 & 0.500 & 0.487 & 0.483 \\
\hline Inequality between country groups & 0.722 & 0.731 & 0.774 & 0.734 & 0.678 \\
\hline Total (global) inequality & 1.175 & 1.214 & 1.273 & 1.221 & 1.160 \\
\hline
\end{tabular}

Source: derived from Sala-i-Martin (2002)

Also this second group of studies suffers from some methodological problems. Indeed, it is impossible to predict the shape of income distribution on the basis of a single statistics (for instance, a Gini coefficient is compatible with an infinite number of Lorenz curves), or it is reasonable to assume that all distributions follow a lognormal pattern. To solve this problem, a third group of analyses relies on individual income data derived from representative household surveys. This approach allows estimating accurately for each year the shape of the income distribution of each country and, by aggregation, the distribution of world income among its citizens. To the best of our knowledge, there are only four studies in this category. The first two (Ravallion et al. 1991 and Chen et al. 1997) comprise only developing countries, while the third (Ravallion and Chen 1997) includes also the transitional economies. The fourth and most complete study is that by Milanovic (2000) which covers also the developed economies. These account for a large share of world output and their exclusion from the analysis affects perceptibly the shape of the global income distribution.

The main problem with this approach is that lack of individual data from household surveys for the earlier years impedes to extend backwards the analysis of changes in global inequality. The study by Milanovic (2000), for instance, refers only to 1988 and 1993 and cannot provide a deeper time perspective of inequality changes. The study makes use of PPP-adjusted survey-derived data on the distribution of income per capita in 1988 and 1993 for 88 countries accounting for 84 percent of the world population and 93 percent of world GDP. Because of their huge size (e.g. rural China represents 18.5 percent of the world population) and of the recent sharp widening of the income gap between their urban and rural areas, the study treats these two sectors of the Chinese, Indian, Bangladeshi, Pakistani and Egyptian economies as separate nations. The study finds that global inequality worsened sharply over 1988-93: the ratio between the average income of the top 5 percent and the bottom 5 percent of the world population rose from 78 in 1988 to 114 in 1993. Meanwhile the Gini coefficient of the world income distribution rose from 0.628 in 1988 to 0.670 in 1993 as a result of a surge in both within-country and between-country inequality. Milanovic concludes his analysis noting that "... slow growth of rural per capita incomes in populous Asian countries (China, India and Bangladesh) compared to income growth of several large and rich OECD countries, plus fast growth in urban China compared to rural China and rural India, were the main reasons why world Gini increased". 
The results of these studies are summarized in Table 4 below and suggest the following tentative conclusions:

- measurement of the level of global inequality and of the direction of its change over the last two decades is influenced by a number of statistical choices concerning the use of GDP versus income per capita, market versus PPP exchange rates, synthetic statistics of the distribution vs. detailed survey data (see footnote 4) and the treatment of China, India and few other poor populous countries either as single nations or as two separate urban and rural sectors. This latter choice is particularly important for the 1990s, a period which witnessed a resurgence of the urban-rural income gap in China (see table 4). In all cases, removing China from the sample raises world inequality.

Table 4. Summary of findings of changes in within country, between country and global inequality over the recent two decades (or similar period)

\begin{tabular}{|c|c|c|c|c|c|c|c|}
\hline & $\begin{array}{l}\text { Period } \\
\text { Covered }\end{array}$ & $\begin{array}{l}\text { Exchange } \\
\text { rate used }\end{array}$ & $\begin{array}{l}\text { Inequality } \\
\text { measure }\end{array}$ & $\begin{array}{l}\text { Within } \\
\text { countries } \\
\text { Inequalit } \\
\mathrm{y}\end{array}$ & $\begin{array}{l}\text { Between } \\
\text { countries } \\
\text { inequality }\end{array}$ & $\begin{array}{l}\text { Total } \\
\text { (global) } \\
\text { inequality }\end{array}$ & $\begin{array}{l}\text { Approach followed and main } \\
\text { assumptions }\end{array}$ \\
\hline UNCTAD (1997) & $1980-90$ & Current & Gini & $\ldots \ldots$ & Up & $\ldots$ & $\begin{array}{l}\text { Uses GDP/c and income } \\
\text { shares }\end{array}$ \\
\hline UNDP (1999) & $1960-97$ & Current & $\begin{array}{l}\text { Quintile } \\
\text { ratio }\end{array}$ & $\ldots \ldots$ & Up & $\cdots$ & Uses GDP/c \\
\hline $\begin{array}{l}\text { Korzeniewicz and } \\
\text { Moran (1997) }\end{array}$ & $1965-92$ & Current & $\begin{array}{l}\text { Gini } \\
\text { Theil }\end{array}$ & $\begin{array}{l}\cdots \cdots \\
\ldots \ldots\end{array}$ & $\begin{array}{l}\text { Up } \\
\text { Up }\end{array}$ & & Uses GDP/c \\
\hline Schultz (1998) & $1968-89$ & PPP & $\begin{array}{l}\text { Gini } \\
\text { Gini(exc. } \\
\text { China) }\end{array}$ & $\begin{array}{l}\mathrm{Up} \\
\mathrm{Up}\end{array}$ & $\begin{array}{l}\text { Down } \\
\text { Stable }\end{array}$ & $\begin{array}{l}\text { Down } \\
\text { Up }\end{array}$ & $\begin{array}{l}\text { Uses GDP/c and income } \\
\text { shares }\end{array}$ \\
\hline $\begin{array}{l}\text { Stewart and } \\
\text { Berry (n.d.) }\end{array}$ & $1980-90$ & PPP & Gini & Up & Down & $\begin{array}{l}\text { Slightly } \\
\text { down }\end{array}$ & GDP/c and income shares \\
\hline $\begin{array}{l}\text { Sala-i-Martin } \\
(2002)\end{array}$ & $1970-98$ & PPP & $\begin{array}{l}7 \text { ineq. } \\
\text { indexes } \\
7 \text { ineq. } \\
\text { indexes } \\
\text { (excl. } \\
\text { China) }\end{array}$ & $\begin{array}{r}\text { Up } \\
\text { Stable }\end{array}$ & $\begin{array}{l}\text { Down } \\
\text { Slightly } \\
\text { up }\end{array}$ & $\begin{array}{l}\text { Down } \\
\text { Slightly } \\
\text { up }\end{array}$ & $\begin{array}{l}\text { GDP/c and quintile shares for } \\
125 \text { countries (for } 57 \text { of them } \\
\text { assumptions made on } \\
\text { shape/stability of distribution) } \\
\text { National trends in quintile } \\
\text { shares are obtain through } \\
\text { linear regression. }\end{array}$ \\
\hline $\begin{array}{l}\text { Bourguignon and } \\
\text { Morissson (2002) }\end{array}$ & $1980-92$ & PPP & $\begin{array}{l}\text { Gini } \\
\text { Theil } \\
\text { MLD }\end{array}$ & $\begin{array}{l}\mathrm{Up} \\
\mathrm{Up}\end{array}$ & $\begin{array}{c}\text { Up } \\
\text { Down }\end{array}$ & $\begin{array}{l}\text { Stable } \\
\text { Up } \\
\text { Down }\end{array}$ & $\begin{array}{l}\text { GDP/c and income shares } \\
\text { to proxy the distribution of } \\
33 \text { large countries/groups }\end{array}$ \\
\hline $\begin{array}{l}\text { Dowrick and } \\
\text { Akmal (2001) }\end{array}$ & $1980-93$ & Afriat & $\begin{array}{l}\text { Gini } \\
\text { Theil } \\
\text { SCV }\end{array}$ & $\begin{array}{l}\mathrm{Up} \\
\mathrm{Up} \\
\mathrm{Up}\end{array}$ & $\begin{array}{l}\text { Slightly up } \\
\text { Up } \\
\text { Up }\end{array}$ & $\begin{array}{l}\mathrm{Up} \\
\mathrm{Up} \\
\mathrm{Up}\end{array}$ & $\begin{array}{l}\text { Uses GDP/c and income } \\
\text { shares }\end{array}$ \\
\hline Milanovic (2000) & $1988-93$ & PPP & $\begin{array}{l}\text { Gini } \\
\text { Theil }\end{array}$ & $\begin{array}{l}\mathrm{Up} \\
\mathrm{Up}\end{array}$ & $\begin{array}{l}\text { Up } \\
\text { Up }\end{array}$ & $\begin{array}{l}\text { Up } \\
\text { Up }\end{array}$ & $\begin{array}{l}\text { Income/c and original } \\
\text { distributions from } 91 \text { nations. } \\
\text { Large Asian countries are } \\
\text { separated into rural and urban }\end{array}$ \\
\hline $\begin{array}{l}\text { Li, Squire, Zou } \\
\text { (1998) }\end{array}$ & $1980-92$ & n.appl. & Gini & Stable & $\ldots$ & $\cdots$ & $\begin{array}{l}49 \text { countries } \\
\text { linear trend regression }\end{array}$ \\
\hline Cornia (2002) & $1980-99$ & & Gini & Up & $\ldots$ & $\ldots$ & 73 countries \\
\hline
\end{tabular}


Source: compilation by the author

- bearing these considerations in mind, the evidence suggests - on balance - that between the early 1980s and 1993 (no analysis extends beyond that year) global inequality increased - if at a slower pace than during the first wave of globalisation because of a moderate rise in between-country. In turn, within-country inequality has clearly risen in many countries (see next section) but its overall impact on global inequality seems to have been less pronounced. The latter conclusion is, however, influenced by the inequality index used.

- the increase in global inequality was probably more pronounced in the 1990s, a period during which the US and other high-income economies expanded rapidly while rural incomes in India and - to some extent - China grew slowly. In contrast, during the 1980s, fast agricultural growth in China and India and recession in the OECD countries - caused quasi-stagnation in global inequality in relation to the 1970 s.

\section{CHANGES IN WITHIN-COUNTRY INEQUALITY}

The previous section has argued that between-country inequality accounts for most of global inequality and its evolution over the last two decades. However, from a policy perspective, within-country inequality is likely to be more important. There are three reasons for this. First, between-country inequality is path dependent and is not easily modifiable by the policies of a single country save, possibly, the US and China. Second, despite the development of global media and international travel, withincountry inequality is much more observable and perceivable than between-country inequality that, for most people, still remains an abstract notion. For this reason, within-country inequality exerts a greater influence on the behaviours of the economic agents than between-country inequality. And, third, most policy decisions affecting the relative income position of the citizens of a country are still taken at the national level. This calls therefore for a greater emphasis on analyses of changes in withincountry inequality. This approach is followed in the next sub-section that reviews the changes in income distribution since the end of World War II - and particularly over the last 20 years - in the main non-developed regions.

\subsection{INEQUALITY CHANGES BY MAIN REGIONS}

(i) Latin America: a rise in inequality in the 1980s followed by a further rise or stagnation in the 1990s. In the 1980s and 1990s, inequality in the region was affected by several external shocks, the recessionary adjustments introduced to respond to them, and widespread external liberalisation. Altogether, the 1980s were characterised by highly regressive outcomes as inequality declined in only three countries (Colombia, Uruguay and Costarica) out of 11 (Altimir, 1996). Iglesias (1998, p.6) notes that '... at the end of the decade, there was a substantial rise in inequality in most cases. That means that the recession of the 1980s hit the poor harder than the rich'. In the 1990s, income polarisation did not decline and in half of the cases it worsened further, if at a

\footnotetext{
${ }^{8}$ In both China and India, agricultural growth was much more rapid in the 1980s than in the 1990s.
} 
slower pace than in the $1980 \mathrm{~s}$, despite the return to full capacity growth and the liberalisation of the external sector. A review of inequality changes over the 1990s based on 49 representative surveys for 15 countries (Székely and Hilgert 1999) shows that inequality worsened in eight cases while it stagnated in seven (see also Morley 2000).

The income polarisation of the 1980s and 1990s was the result of fast inequality rises during recessionary spells and slow declines during periods of recovery (Cornia, 1994). As a result, between 1980 and the late 1980s, the labour share declined by 5-6 percentage points in Argentina, Chile and Venezuela and ten in Mexico (Sainz and Calcagno, 1992) while such tendency was not reversed in the 1990s. In several countries - as in Chile during the military dictatorship - the fall in the labour share was due also to the regressive changes in labour legislation that relaxed regulations on workers dismissals, restricted the power of trade unions, suspended wage indexation, cut public employment and restricted the coverage of the minimum wage while, at the same time, wealth and capital gains taxes were eliminated, profit taxes substantially reduced and interest rates sharply risen. Five structural trends emerged in the labour market as a result of these policy changes and of the stagnation of the 1980s (Tokman 1986) and slow growth of the 1990s. First, sluggish growth brought about a slowdown in jobs creation. Second, informal employment (in sectors where low wages are the rule) became much more common. Third, formal sector wages evolved less favourably than GDP per capita. Fourth, minimum wages mostly fell in relation to average wages. Fifth, wage differentials by skill level widened, particularly during the 1990s, in parallel with widespread trade and financial liberalisation (Székely and Hilgert 1999). This review may be concluded by noting with Altimir (1996, p.59) that:

Under these new economic modalities (characterised by trade openness,

fiscal austerity, a prudent management of monetary policy, less public

regulation of markets and more reliance on private initiative), the pattern

of income distribution tends, as suggested above, to be unequal at the

very least, and more unequal - in most cases, at least in urban areas -

than those [already high] that prevailed during the last stages of the

previous growth phase in the 1970s.

(ii) China: a U-shaped trend in regional and urban-rural inequality. Over the last 50 years, income inequality in China followed a clear U-shaped pattern. At the start of the Maoist reforms in 1953, the nationwide Gini coefficient of the distribution of household incomes stood at a high 0.56 . The reforms of the 1950s and 1960s rapidly reduced income polarisation and, by 1975, the Gini index had fallen to 0.26 despite large regional differences in natural endowments (Table 5). The reforms adopted in agriculture since 1978 replaced the rural communes with an egalitarian family-based agriculture and introduced considerable price incentives for the farmers. The result was a sharp acceleration of agricultural and overall growth between 1978 and 1984. During these years, there was only a modest upsurge in inequality and rural poverty was literally halved, falling from 30.7 to 15.1 percent between 1978 and 1984 (Gustafsson and Zhong 2000).

Table 5. Evolution of the Gini coefficients and the income gap in China, 1953-98 


\begin{tabular}{cccccccc}
\hline Year & $\begin{array}{c}\text { Overall } \\
\text { Gini }\end{array}$ & $\begin{array}{l}\text { Urban } \\
\text { Gini }\end{array}$ & $\begin{array}{l}\text { Rural } \\
\text { Gini }\end{array}$ & $\begin{array}{l}\text { Income gap } \\
\text { U/R }\end{array}$ & $\begin{array}{l}\text { Inter- } \\
\text { Provincial } \\
\text { Income } \\
\text { gap(rural) }\end{array}$ & $\begin{array}{l}\text { Inter- } \\
\text { Provincial } \\
\text { Income } \\
\text { gap(urban) }\end{array}$ & $\begin{array}{l}\text { Inter- } \\
\text { Provincial } \\
\text { Income } \\
\text { Gap(total) }\end{array}$ \\
\hline 1953 & $0.56^{\mathrm{c}}$ & $\ldots \ldots$ & $\ldots$ & $\ldots$ & $\ldots \ldots$ & $\ldots$ & $\ldots$ \\
1964 & $0.31^{\mathrm{c}}$ & $\ldots \ldots$ & $\ldots$. & $\ldots$ & $\ldots \ldots$ & $\ldots$ & $\ldots$ \\
1975 & $0.26^{\mathrm{c}}$ & $\ldots \ldots$ & $\ldots$ & $\ldots$ & $\ldots$. & $\ldots$ & $\ldots$ \\
1978 & 0.32 & 0.16 & 0.21 & 2.37 & $\ldots \ldots$ & $\ldots$ & $\ldots$ \\
1981 & $\ldots \ldots$ & 0.15 & 0.24 & 2.05 & 2.80 & 1.81 & 12.62 \\
1984 & $0.28^{\mathrm{d}}$ & 0.16 & 0.26 & 1.71 & $3.16^{\mathrm{e}}$ & $1.59 \mathrm{e}$ & $9.22^{\mathrm{e}}$ \\
1988 & 0.38 & 0.23 & 0.30 & 2.05 & $\ldots \ldots$ & $\ldots \ldots$ & $\ldots \ldots$ \\
1990 & $\ldots$. & 0.23 & 0.31 & 2.02 & 4.17 & 2.03 & 7.50 \\
1995 & 0.43 & 0.28 & 0.34 & 2.47 & 4.82 & 2.34 & 9.79 \\
1998 & $0.41^{\mathrm{c}}$ & $\ldots \ldots$ & $\ldots$ & $\ldots$ & $\ldots \ldots$ & $\ldots$ & $\ldots$ \\
\hline
\end{tabular}

Source: State Bureau of Statistic and World Bank (2000). Notes: ${ }^{a}$ ratio between the average urban and rural average income; ${ }^{b}$ ratio between the average income of the highest to the lowest province, by rural, urban and total area; ${ }^{c}$ data for these years are not comparable with those of the other years and are only illustrative of the broad level of inequality of that year; ${ }^{\mathrm{d}}$ refers to 1983 ; ${ }^{\mathrm{e}}$ refers to 1985 .

In contrast, inequality rose fast between 1985 and 1990 and very fast after 1990 (Table 5). This increase can be traced to a widening of the urban-rural gap driven by rapid urban-based industrialisation, export-led growth in the coastal area and neglect of the poor interior regions and of agriculture (Ping 1997). For example, over 1993-8, the Chinese farmers suffered a 30 percent fall in the price of grains and a tripling of agricultural taxes. Such trends exasperated the urban-rural gap and reduced the pace of rural poverty alleviation which slowed down sharply over 1984-95, the years of the export boom, in relation to 1978-84, the years of agricultural growth (Gustafsson and Zhong 2000).

Public policy was a major determinant of this rise in income polarisation. The fiscal decentralization introduced in 1978 substantially reduced the possibility of the central Government to control regional inequality by means of transfers to poorer provinces. Industrial and export-growth policy - deliberately pursued in a regionally unbalanced manner - plaid an even greater disequalizing role, as it favored the coastal provinces through the granting of special administrative and economic powers, tax privileges and other benefits which facilitated the development of export industries and the inflow of foreign direct investment.

(iii) East and Southeast Asia: a common if milder and more recent reversal of inequality trends. Countries from this region are well known for having achieved in the past an equitable export-led growth. Yet, since the 1980s, and particularly the early 1990s, inequality rose also in most of the region. In South Korea the Gini coefficient of the earnings distribution declined steadily over time owing to a narrowing of wage differentials by occupation, gender and level of education (Fields and Oyo 2000). Both wage and income inequality rose again, however, in the aftermath of the 1997 crisis. The full-capacity unemployment rose from 1-2 to 4-5 percent between 1995-6 and 19992000 (KLSI, 2001), while the share of part time and daily workers in the total jumped from 42.5 to 52.5 percent between 1996 and 2000 and the wage spread by employment type widened. As a result, between 1996 and 1999, the labour share fell from 64 to 60 percent while the Gini coefficient of the distribution of earnings rose from 0.29 to 0.32 . 
In Taiwan, income inequality improved steadily between 1964 and 1980 thanks to a rapid expansion of employment among skilled and unskilled workers employed in the domestic and export sector. Over 1980-1993, however, the development of the skillintensive sectors pushed up again - id moderately - wage inequality, while the share of capital incomes in the total surged in line with the development of large corporations and the escalation of land prices. By 1993, Taiwan reached again the inequality level of 1964. Hong-Kong and Singapore too show a mild U-shaped pattern, with fairly rapid inequality declines till the late 1970s, followed by moderate rises offsetting half of the earlier falls (Oshima, 1998).

Except for Thailand, the economies of Southeast Asia also follow a pattern of inequality decline between the 1960s and the mid-1980s followed by a rise during the 1990s. In Thailand, the Gini coefficient of the distribution of total income rose steadily (from 0.41 to 0.52 ) since the $1960 \mathrm{~s}$ and particularly during the 1990s. Since the mid-late $1980 \mathrm{~s}$, this trend is explained by a surge in the share and concentration of non-farm profits linked to the rapid expansion of the globalisation-related finance, insurance, internet and real estate (F.I.I.R.E.) sector in the Bangkok area (Sarntisart 2000).

In Indonesia, the Gini coefficient of the distribution of income fell from 0.35 in 1964-5 to 0.32 in 1987 thanks to the recycling of the oil rent to the financing of the 'green revolution'. This substantially raised employment and production opportunities in agriculture, reduced rural inequality and fostered rural growth and poverty reduction (Feridhanusetyawan 2000). In contrast, the years from 1987 to 1996 - a period characterised by devaluation, tariff reform and financial deregulation - were characterised by the development of the urban-based manufacturing and capitalintensive F.I.I.R.E. sector, a slow down of agriculture, a widening of the urban-rural gap, the retrenchment of rural development programs and, as a result, a rise in overall inequality from 0.32 in 1987 to 0.38 in 1997 (ibid.). In the immediate, the Asian financial crisis of 1997 led to a marginal drop in inequality as middle-high income people employed in the F.I.I.R.E. sector were immediately affected. Shortly after, however, inequality and poverty rose especially fast among the urban poor - due to the recession induced by the crisis, the stabilisation measures introduced to combat it and the differential impact of price rises which affected the poor the most (Levinshon et al 1999). In a summary analysis of the impact of the Asian crisis, Pangestu (2000) and Knowles et al (1999) found that over 1997-98 inequality dropped marginally in Indonesia and rose in Thailand, the Philippines and South Korea.

(iv) The late liberalizers of South Asia. By and large, during the post-World War II period, income distribution in the region changed less than elsewhere, though following the changes of the last decades - it now appears it also followed a mild Ushaped pattern. In India, the Gini coefficient of household consumption expenditure per capita fell from 0.36 to 0.31 over 1951-61 and then fluctuated in the 0.29-0.32 range until the introduction in July 1991 of the first IMF stabilisation and liberalisation programme. In the 1980s, stable inequality, substantial expenditure on rural development and a 4 percent growth in agriculture led by the 'green revolution' reduced substantially rural poverty. 
With the gradual liberalisation of the economy in the 1990s, GDP growth accelerated to 5.6 percent. Such growth was, however, highly concentrated in the urban sector, by regions and by income group. While fast urban growth and a moderate rise in urban inequality (whose Gini coefficient rose from 0.34 to 0.36 ) allowed for a decline in urban poverty, rural poverty stagnated owing to slow agricultural growth, cuts in rural development programs and food subsidies and a rise in rural inequality (Mundle and Tulasidhar 1998, Jha 2000). In sum, the experience of the 1990s points to a moderate rise in both urban and rural inequality, a larger rise in overall inequality due to the widening of the urban-rural gap and a decline in the poverty alleviation elasticity of growth (Ravallion and Datt 1999). In Sri Lanka, Bangladesh and Pakistan inequality followed also a mild Ushaped pattern. In Pakistan, for instance, the Gini coefficient declined from .39 to 0.33 during the growth years of 1963-1973 but gradually climbed back to reach 0.41 in 1992-93 (Oshima, 1998). As in Bangladesh, the inequality reversal is more pronounced in the rural sector where an initial drop of 7 Gini points was followed by a rise of 12 points.

(v) Sub-Saharan Africa: falling urban-rural gap, but rising intra-urban and - at times - intra-rural inequality. Conclusions about inequality changes in Sub-Saharan Africa are tentative, as - despite some improvements - there are still few nations with at least two comparable surveys spanning the last twenty years.

In the past, inequality was the fruit of a large urban-rural income gap inherited from the colonial era and reinforced by the "urban bias" of post-colonial policy. The 1980s and 1990s were characterised by the massive application of adjustment programs aimed at improving the rural terms of trade and stimulating agricultural exports. These reforms succeeded in liberalising the economy, devaluing the real exchange rate (which fell on average by 30 percent over 1980-1998) and opening up the African economies, as signalled by the rise from 51 to 62 percent in the regional import plus export ratio to GDP (Kayizzi-Mugerwa 2000). In spite of this, GDP per capita stagnated. Even in the few regional success stories (Uganda and Ghana), the recovery remained fragile while labour-intensive manufacturing exports did not take off. Mauritius is the main exception. It successfully increased textile exports and liberalised the financial sector while experiencing rapid growth, a surge in employment in the export sector and falling inequality (Table 6).

The impact of policy reform and output stagnation was the hardest in the urban sector that, in several cases, experienced a drop in its terms of trade and large income falls. Rural areas were less affected or gained, as in the case of Uganda. Thus, in most cases, the urban-rural gap was reduced by a process of 'equalising downward' (UNCTAD, 1997). Intra-rural inequality rose in countries - such as Kenya - characterised by a high land concentration (Table 6) or where the recovery was peasant-based but where the improved earning potential failed to reach the remote areas due to inadequate infrastructure or the collapse of marketing arrangements - as in Zambia (Mc Culloch et

\footnotetext{
${ }^{9}$ Many argue that such modest increase in inequality contrasts with the growing capitalisation of the Bombay stock market, and that it likely reflects the undersampling of the new high-income groups from the National Sample Survey - as confirmed by the growing divergence between the estimates of the average consumption per capita measured on NSS and national accounts data.
} 
al 2000). Inequality generally improved in countries such as Mozambique and Uganda caricaturised by a peasant agriculture rebounding from years of civil strife (Bigsten 2000).

Table 6. Gini coefficients of the distribution of income in the rural, urban and overall economy

\begin{tabular}{|c|c|c|c|c|}
\hline Country & Year & Rural & Urban & Overall \\
\hline Cote & 1970 & … & $\ldots$ & 0.53 \\
\hline \multirow{2}{*}{ d'Ivoire } & 1985 & & & 0.39 \\
\hline & 1995 & & & 0.37 \\
\hline \multirow[t]{2}{*}{ Kenya } & 1982 & 0.40 & ..... & $0.52\left({ }^{`} 76\right)$ \\
\hline & 1992 & 0.49 & & $0.58(' 84)$ \\
\hline \multirow[t]{2}{*}{ Mauritius } & 1986 & $\ldots \ldots$ & ..... & 0.40 \\
\hline & 1991 & & & 0.37 \\
\hline \multirow[t]{2}{*}{ Ethiopia } & 1989 & 0.41 & $\ldots$ & $\ldots \ldots$ \\
\hline & 1994 & 0.46 & & \\
\hline \multirow[t]{2}{*}{ Tanzania } & 1983 & 0.53 & $\ldots$ & $\ldots$ \\
\hline & 1991 & 0.76 & & \\
\hline \multirow[t]{2}{*}{ Nigeria } & 1986 & ....... & $\ldots$ & 0.37 \\
\hline & 1993 & & & 0.42 \\
\hline \multirow[t]{3}{*}{ Uganda } & 1989 & $\ldots$ & 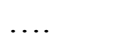 & 0.33 \\
\hline & 1992 & 0.33 & 0.43 & 0.38 \\
\hline & 1998 & 0.32 & 0.37 & 0.36 \\
\hline \multirow[t]{3}{*}{ Zambia } & 1991 & 0.56 & 0.45 & 0.56 \\
\hline & 1996 & 0.49 & 0.47 & 0.52 \\
\hline & 1998 & 0.52 & 0.48 & 0.51 \\
\hline
\end{tabular}

This nuanced picture is broadly confirmed by a review of the 1990 s changes in the expenditure distribution (Christiaensen et al 2002) for Ethiopia, Uganda, Zimbabwe, Ghana, Madgascar, Zambia and Mauritania. The study finds that rural inequality declined in 5 cases out of 7 thanks to domestic trade liberalisation, changes in agricultural procurement policies and greater macroenomic and political stability. In contrast, urban inequality rose in 4 out of 7 cases while overall inequality rose in three cases and fell in another three. The changes recorded were generally quite modest though this apparent stability hides considerable micro churning.

(vi) A sharp rise of inequality in the former Soviet Bloc. Since 1989, concurrently with the privatisation and domestic and international liberalisation of these economies, income concentration rose moderately in the countries of Central Europe (Milanovic, 1998) where earnings inequality widened less than expected and a comprehensive welfare state was preserved or even expanded. In contrast, in the former USSR and South Eastern Europe, Gini coefficients rose on average by an astounding by 10-20 points, i.e. 3-4 times faster than in Central Europe (Table 7). In these countries, the transitional recession and fall in the wage share were extremely pronounced, social transfers declined, their composition and targeting deteriorated (Cornia 1996) and privatisation was less equitable than in Central Europe.

Table 7. Gini coefficients of the distribution of net per capita disposable household income between 1989 and 1994-95

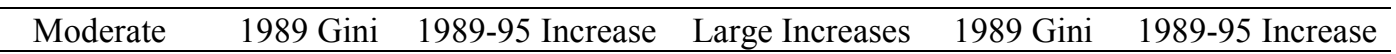




\begin{tabular}{lllllc}
\hline \multicolumn{1}{c}{ Increases } & \multicolumn{5}{c}{} \\
\hline Slovenia & 23.7 & 1.3 & Lithuania & 27.5 & 8.5 \\
Hungary & 21.4 & 1.6 & Latvia & $22.5^{\mathrm{a}}$ & 8.5 \\
Slovakia & 19.5 & 3.0 & Estonia & 27.7 & 11.9 \\
Romania & 23.5 & 4.9 & Bulgaria & $25.0^{\mathrm{b}}$ & 12.0 \\
Czech Republic & 18.5 & 4.9 & Moldova & 26.7 & 13.3 \\
Poland & 24.9 & 5.1 & Russia & 25.7 & 15.2 \\
& & & Ukraine & $23.3^{\mathrm{a}}$ & 24.1 \\
\hline
\end{tabular}

Source: UNICEF (1997); Milanovic (1998) for Latvia and Ukraine. Notes: a. 1988. The data are not always directly comparable over time due to changes in the sampling framework. For a few countries and years the data refer to gross household income per capita. b. 1990.

Rising earnings inequality seems to have played a central role in the surge of income inequality (Milanovic 1998). The rise in the wage gap has been attributed to the emergence of "scarcity rents" for professionals such as bankers and other specialists undersupplied during the old system, and to a physiological rise in returns to education following the liberalisation of the labour market (Rutkowski 1999). Such explanations, based on standard human capital theory, account however for less than half of the observed increase. Indeed, many educated employees in the public sector continued to receive low wages unrelated to their skills and experience. Earnings inequality appears to have risen also because of the fall in the minimum wage relative to the average, the expansion of a poorly regulated and inequitable informal sector, mounting wage arrears and a surge in interindustrial wage dispersion favouring politically influential sectors such as mining and power generation (Cornia, 1996). The limited rise in capital incomes reported by the literature (Milanovic 1998) is likely the result of the undersampling of the new high-income groups and to the underreporting of their income in the Household Budget Surveys as suggested by the growing discrepancy between the income per capita derived from the national accounts and the household surveys and by the growing concentration of financial assets.

\subsection{ECONOMETRIC ANALYSIS OF WITHIN-COUNTRY INEQUALITY}

The above review suggests that, during the last two decades, inequality increased within most of the countries analyzed and that such rise often represented a reversal of the inequality decline observed during the first two-three decades of the post World War II period. Such result conflicts however with the findings of prior research in this area that has pointed to the broad stability of within-country inequality over the 1950-1990 period. For instance, after fitting linear trends to 49 country data, Li, et al. 1998, (p.35) conclude that " .. there is no evidence of a time trend in 32 countries or $65 \%$ of our sample". Examination of the estimation procedure followed in this and similar studies suggest, however, that these conclusions are dependent on the methodology adopted. Indeed, the sample utilised did not include most economies in transition (which experienced a universal rise in inequality in the 1990s), extended only up to 1991-93 (and so missed the disequalizing impact of recent financial crises) and was fitted only with linear trends (i.e. a functional form that does not permit to capture trend reversals). Finally, the country results were not weighted by population size and GDP-PPP.

Cornia with Kiiski (2001) tried to overcome the limitations of this literature. They extracted from the November 1998 version of WIDER's World Income Inequality 
Database (WIID) 770 "reliable observations" of Gini coefficients for 73 countries 10 that account for 80 and 91 percent of the world population and GDP-PPP. These coefficients are derived from fully documented, comparable and representative surveys of the entire economy and refer to "per capita household disposable income" in 52 countries, "per capita consumption expenditure" in nine countries; and "gross earnings" in 14 economies in transition. Each country's time series (that makes use of the same income concept for the entire period analysed) were interpolated with linear as well as quadratic functions (so as to capture trend reversals). For each country, the best functional form was selected on the basis of the most significant $t$ statistics and, as a subordinate criterion, the highest R2. The results of these trend estimates are summarised in Table 8 .

Table 8. Trends in income inequality from the 1950s to the mid 1990s for 73 developed, developing and transitional countries.

\begin{tabular}{|c|c|c|c|c|c|c|}
\hline & $\begin{array}{l}\text { Sample } \\
\text { countries in } \\
\text { each group } \\
\text { Developed }\end{array}$ & $\begin{array}{l}\text { Sample } \\
\text { countries in } \\
\text { each group } \\
\text { Developing }\end{array}$ & $\begin{array}{l}\text { Sample } \\
\text { countries in } \\
\text { each group } \\
\text { Transitiona }\end{array}$ & $\begin{array}{l}\text { Sample } \\
\text { countries in } \\
\text { each group } \\
\text { Total }\end{array}$ & $\begin{array}{l}\text { Share of } \\
\text { population } \\
\text { of total } \\
\text { sample } \\
\text { countries }\end{array}$ & $\begin{array}{l}\text { Share of } \\
\text { GDP-PPP } \\
\text { of total } \\
\text { sample } \\
\text { countries }\end{array}$ \\
\hline $\begin{array}{l}\text { Rising inequality of } \\
\text { which: }\end{array}$ & 12 & 15 & 21 & 48 & 59 & 78 \\
\hline U shaped & $\ldots \ldots$ & $\ldots \ldots$ & $\ldots \ldots$ & 29 & 55 & 73 \\
\hline Constant inequality & 2 & 14 & $\mathbf{0}$ & 16 & 36 & 13 \\
\hline Falling inequality & 2 & 5 & 2 & 9 & 5 & 9 \\
\hline Total & 16 & 34 & 23 & 73 & 100 & 100 \\
\hline
\end{tabular}

Source: author's calculations on the November 1998 version of WIDER's WIID.

These results broadly confirm the conclusions arrived at on the basis of the review of case studies presented in section 4.1. Inequality was found to have risen in 48 of the 73 countries analyzed, including in large economies such as China, several large Latin American nations, the USA and Russia. Inequality was found to have remained constant in 16 countries (including Germany and Brazil, as well as medium or large countries such India, Indonesia and Tanzania for which the most recent data reviewed in section 4.1 show, however, a perceptible reversal of the inequality trend). Only in nine countries there is evidence of a decline in income concentration over the long-term. These include some small countries (Bahamas, Honduras, and Jamaica, Tunisia) and a few medium sized ones (France, Malaysia, South Korea). Weighing the results by population size and GDP-PPP, strengthens the conclusions (see the last two columns of Table 8).

As noted, the November 1998 version of WIID extends only up to 1994-5. Because of this, the results in Table 8 do not reflect the inequality changes intervened during the last 5-6 years. We, thus, separately moved India, Indonesia, South Korea, Tanzania and the Philippines - all countries that recently experienced inequality reversals (see section $4.1)$ - to the 'rising inequality' category. In this way, of the 73 countries in the sample, 53 experienced a surge in income concentration over the last 20 years. This increase was universal in the economies in transition, almost universal in Latin America and

10 Of these 73 countries 32 are developing, 21 transitional economies and 18 from the OECD. Except for Africa, these countries account for 84 to 98 percent of the population and 82 to 98 percent of the GDP-PPP of these regions. For Africa, the six countries included in the analysis account for 18 and 32 percent of the total population and GDP-PPP. 
increasingly frequent, if less dramatic in South, SouthEast and East Asia. In sub-Saharan Africa, domestic liberalisation may have improved the agricultural terms of trade but failed to induce - with few exceptions - an expansion of inequality-reducing labour intensive exports.

The observed increase in the Gini coefficients was often substantial. Of the 53 countries with growing inequality, the rise was of between 5 and 10 Gini points in 30 nations (in 9 of them it occurred from initial levels of $0.40-0.45$ ), by between 10 and 20 points in 10 countries and by more than 20 points in a couple of countries of the former Soviet Union. In many countries, greater income polarisation seems to have been driven by both a fall in the labour share (paralleled by a rise in the capital share) and a worsening of the earnings distribution explained only in part by a rise in returns to education. Growing regional disparity and growth concentration in the urban areas were also key factors.

\section{CAUSES OF THE RECENT CHANGES IN INEQUALITY}

Section 4 has argued that both between- and within-country inequality have risen over the last two decades. While the upward impact on global inequality was moderate by historical standards, such increase is perplexing if seen in relation to the predictions of the standard theory and if juxtaposed to the fall in within-country inequality which took place between 1950 and $1970-5$ following the adoption of full-employment and redistributive policies in the OECD and socialist economies, and of the land, educational and employment reforms adopted in the East Asian countries, China and to an extent - India. What factors account for such trend reversals? One can, alternatively, propose three sets of explanations:

(i) An aggravation of the traditional causes of inequality? The first - and least plausible - explanation of the recent rise in income polarisation focuses on an aggravation of the traditional causes of inequality such as land concentration. Yet, changes in this area cannot explain the recent surge in inequality for the reasons adduced below.

In developing countries, high land concentration has been and remains a major determinant of rural inequality. Yet, during the last 50 years the share of agriculture in total output and employment has fallen everywhere, while over the 1950s and 1960s land reforms redistributed latifundia and state land to poor farmers in at least 27 countries. As a result, land rents and rural inequality have declined. Second, while countries well endowed with mineral resources are known to have a high income and asset inequality, such 'curse of natural resources' hardly explains the income polarisation of the last two decades, as the mineral rent/GDP ratio has systematically declined since the late 1970s (Cornia with Kiiski, 2001). Third, the same conclusion applies - with some qualification - to an hypothetical aggravation of the 'urban bias'. Indeed, a recent review of such bias in the globalised world economy (Eastwood and Lipton 2001) finds no evidence of systematic change, though the bias appears to have declined in Latin America and parts of Africa and increased in post-1984 China, Thailand and Indonesia. 
Finally, greater inequality in the 1980s and 1990s might be ascribed to a worsening in the distribution of educational achievements. Mean educational achievements increased in most countries during the last two decades. Yet, in Latin America, a rise in the average number of years of education was accompanied by mounting educational inequality - as public policy emphasised the reduction of illiteracy (a measure that reduces educational variance) together with a rapid expansion in the number of university graduates (a measure that raises educational variance) (Morley 2000) Differences in educational achievements thus continue to be a key determinant of wage polarisation in the region (Fiszbein and Psacharopulos 1992) while the slow growth in the number of secondary school graduates likely contributed to sluggish growth in manufacturing exports inspite of trade liberalisation. In Africa and, to a lesser extent, the former Soviet Union the difficulties experienced in sustaining primary education in the 1980s and 1990s and the surge in private secondary and higher education will have a disequalizing impact on the future distribution of human capital. In Africa, however, two thirds of the population are still engaged in simple tasks so that the impact of growing polarisation in educational achievements on inequality may remain limited for some years. In contrast, the East and Southeast Asian and Middle Eastern educational policy, focused on an expansion of universal secondary education and so helped reducing educational inequality and wage concentration.

(ii) Technological change. A second - not entirely satisfactory - explanation ascribes the recent rise in within-country inequality to technological change. The latter - it is argued - generates a demand for new skills that chronically outstrips its supply and so creates scarcity rents for skilled workers. International comparisons, however, suggest that whether the relative earnings of educated workers rise depends not so much on technology but on government's investments in secondary and higher education. For instance, Murphy et al. (1999) compare the situation of the US (where governments invested little in public education and the wage premium for college workers rose by over 20 percent between 1980 and 1995) with that of Canada (where this ratio remained constant owing to considerable public investments in education and training). They conclude that, while technological change does raise the relative demand for educated workers, governments control powerful policies for counteracting the unwanted inequality side effect of technological progress.

It is also argued - even when assuming a balanced evolution of the demand and supply of new skills - that new technologies generate an earnings distribution more skewed than that emanating from old technologies. Especially in the service sector and a few industrial branches, new technologies replace unskilled labour with skilled labour and capital embodying new technologies and so affect the labour share in total income and the wage spread. In support of this argument, the World Bank (2000) suggests that the shift towards skill-intensive employment observed in the Western world in the 1970s and 1980s is being matched in a number of developing countries in the 1990s. Yet, this viewpoint does not apply to the many developing countries where either inequality started increasing ahead of this decade of technological modernisation or, as in Africa and Eastern Europe, where low investment rates have impeded a significant

\footnotetext{
11 In Latin America the standard deviation of education has risen from 3 years in 1960 to over 4.5 years in the mid 1990s (Morley 2000).
} 
technological modernisation. Thus, with the exception of a few middle income countries, the evidence in support of such thesis seems, on balance, weak.

(iii) Domestic and external liberalisation. The third - and most relevant - set of explanations pivots around the disequalizing impact of liberalisation and globalisation. Standard theory posits that trade liberalisation in poor countries switches production from non-tradeables and inefficient import-substitutes towards efficient exportables, thus raising the demand for unskilled labour in which the reforming countries are supposed to have a comparative advantage. In turn, capital account liberalisation is expected to raise investment, employment, labor productivity and growth in poor countries with low capital accumulation but high rates of return on investment, with favorable effects on equity and poverty.

The real-life impact of these reforms is, however, more complex and conclusions about their impact depends on the methodology used for their evaluation (cross country regressions, simulations with CGE models, before-after comparisons), the regions analysed and the specific policy mixes considered. Conscious of all this, we first review the literature on the equity impact of the overall reform package, then move to a separate examination of the equity impact of trade and financial liberalisation. Finally, we briefly discuss the impact of those domestic policies that often accompany external liberalisation.

- Impact of the overall liberalisation-globalisation package. There are only few review-studies on the distributive effect of these reforms. Behrman et al (2000) review the impact on wage differentials of the overall reform packages introduced in 18 Latin American countries over 1980-98. They focus on six types of economy-wide reforms, i.e. trade liberalisation, capital account liberalisation, domestic financial liberalisation, privatisation, tax reform and labour market reform. The authors found that the overall package has a significant short-term disequalizing effect on wage differentials $\frac{12}{2}$, the intensity of which, however, declines over time. They also find that the strongest disequalizing impact was due to domestic financial reform, capital account liberalisation and tax reform. Trade openness had, on balance, no net effect on the wage spread, possibly because its many effects cancelled each other out. The authors tentatively suggests that technological progress - rather than trade - is the channel through which liberalisation affects wage inequality.

Broadly similar evidence is provided by a review of the impact of liberalisation during 21 reform episodes in 18 countries (13 from Latin America plus India, South Korea, Turkey, Russia and Zimbabawe) during the last two decades (Taylor 2000). Income inequality was found to rise in 13 cases, remain constant in 6 and improve in two. Virtually without exception, wage differentials by skill level rose following liberalisation, as a result of a reduction of employment in the modern sector, a rise in productivity and wage concentration by skill within the same, the reallocation of excess labour to the low-paying non-traded sector (informal trade, services and traditional agriculture) and a rise of inequality within the latter. Of the 18 countries analysed, only El Salvador and Costa Rica managed to reduce inequality on occasion of liberalisation

\footnotetext{
12 However, a similar review of the impact of policy reform in Latin America during the same period, Morley (2000) arrives to somewhat contradictory conclusions.
} 
thanks to a surge in the employment of unskilled workers in the export sector. In turn, Cornia with Kiiski (2001) evaluate the impact of liberalisation by means of an overall reform index developed by the World Bank. Their regression analysis is carried out on a sample of 32 developing and transitional economies for the years 1980- 95 and suggests that while the reform package had an overall disequalizing effect, this was more pronounced in the economies of the former Soviet bloc, probably on account of their institutional weakness, while it was less pronounced in those with high initial inequality.

In a careful study of the poverty impact of IMF-World Bank reform programs (which comprise macroeconomic stabilisation and structural adjustment measures) Easterly (2001) finds that these moderated the rise of poverty during output contractions, possibly because of the cushioning of the crisis through Bank-sponsored, adjustmentrelated 'social safety nets'. But he also finds that, during spells of economic expansion, Fund-Bank programs reduced the poverty alleviation elasticity of growth in relation to those of 'home-grown' adjustment programs. This would suggest that Fund-Bank programs entail a worsening of income inequality during this process (Table 9). For instance, in China - a country with medium inequality and no Fund-Bank program poverty incidence fell over 1990-2 by 3.8 percent for every point of GDP growth, while in 1995-6 Colombia - a country with high inequality and a Fund-Bank adjustment loan experienced zero poverty reduction for every point of GDP growth (Table 9).

Table 9. Poverty elasticity of growth for different Gini coefficients and IMF- World Bank adjustment loans per year

\begin{tabular}{|c|c|c|c|}
\hline & \multicolumn{3}{|c|}{$\begin{array}{c}\text { Average number of IMF-World } \\
\text { Bank adjustment loans per year } \\
\text { During survey spell }\end{array}$} \\
\hline Gini coefficient & 0 & 0.5 & 1.0 \\
\hline 30 & -3.8 & -2.7 & -1.7 \\
\hline 45 & -2.9 & -1.9 & -0.9 \\
\hline 60 & -2.1 & -1.0 & 0.0 \\
\hline
\end{tabular}

Source: Easterly (2001), Table 3

Though the above studies do not trace all causal linkages between liberalisation, globalisation and inequality, the evidence reviewed as well as other studies omitted here for reasons of space suggest that - especially for economies with weak domestic conditions and institutions - the overall liberalisation package often leads to a deterioration in within-country inequality owing to the incomplete switching of resources from the non-tradable to the tradable sector which entails a fall in modern sector employment, a rise in wage differential within the same and a swelling of the informal sector, as well owing to a decline in the wage share and a rise in the capital share linked to increasing banking and financial instability and to the reform of the labour market and taxation. Of the six components of the liberal package, capital account liberalisation appears to have the strongest disequalizing effect, followed by domestic financial liberalisation, labor market deregulation and tax reform. Privatisation of land was found to improve equity and growth in many cases while that of industrial assets and utilities was associated with rising inequality in some regions (Eastern Europe and former Soviet Union) but not always in others (Latin America). The equity effects of trade liberalisation appear to vary from country to country. The impact was favourable in the 1960s and 1970s in East Asia, in a few small countries (El Salvador, 
Costarica, Mauritius) in recent times and - at the margin - in China and Vietnam, but not in the large Latin America countries, Eastern Europe and most of Africa.

- Trade liberalisation. As noted above, standard theory predicts that trade liberalisation will improve between-country inequality, within-country inequality in poor countries and, by implication, global inequality (in most cases). Analyses on the 1960s and 1970s seem to support these conclusions. Bourguignon and Morisson (1989) analyse the determinants of inequality in 35 small and medium developing countries and conclude that the phased removal of trade protection in manufacturing reduces the income of the richest 20 percent of the population and improves that of the bottom 60 percent. A similar view is offered by Adrian Wood (1984) in his well-known book that shows that trade liberalisation diminished wage inequality in the East Asian exporters of labour intensive manufactures ${ }^{\mathrm{L} 3}$. Yet, the last twenty years offer a less encouraging picture than that just presented. Indeed, evidence for the last two decades shows that trade liberalisation widened the wage gap in a broad range of countries including the East Asian exporters of manufactured goods. For instance, wage inequality was found to have increased in six out of seven Latin American countries for which reliable wage data are available, as well as in the Philippines and Eastern Europe (Lindert and Williamson 2001). One explanation of this phenomenon pivots around a choice of technologies inconsistent with local factors endowments. The import of world class investment goods incorporating the latest technological advances by firms operating in the export sector of developing countries leads to a rise in the demand of skilled rather than unskilled labour. A second explanation pivots around the so called 'fallacy of composition' which argues that the historical context under which trade liberalisation took place in the 1990s was very different from that under which it occurred in the 1960s. The Mexican trade liberalisation of 1985-90, for instance, was accompanied by a widening of its wage distribution as the country had to face intense competition from the entry into the world market for low skill manufactured exports of China, Indonesia and other exporters with substantially lower wages than Mexico. The formal sector of middle income countries no longer has a comparative advantage in labour-intensive exports and either it informalizes its production via a long chain of subcontractors or shifts production towards skill-intensive exports in markets where, however, they face stiff competition from the advanced economies. Third, in the case of low-tech African exporters, trade liberalisation has led to unsatisfactory export growth because of a combination of weak domestic conditions and persistent protectionism in the OECD countries. In a recent review of protectionist tendencies in Northern countries, and in the United States in particular, Slaughter (2000) concludes that current trade barriers in the North appear to cost Southern countries billions of dollars annually. He also finds that while some WTO-governed trade barriers in the North are declining, it appears that there is increasing US resistance to further globalisation via trade and immigration liberalisation. All in all, the predictions of standard trade theory do not seem to hold much in the globalised world of the 1990s. Alternative theoretical approaches, such as those stressing the imports of world class technology, structural inflexibilities, fallacy of composition, persistent protectionism and a changing political economy of distribution in a world of mobile capital and immobile labour may better explain the recent trends in this area (Rodrik1997).

13 As noted in section 2, such decline was reversed in the 1980s and 1990s in most of these countries. 
Standard theory predicts also that foreign trade will reduce between-country inequality. In a longer-term analysis of the effects of trade, Barro (1991) and Sachs and Warner (1997) found that trade distortions are associated with slow growth and that trade liberalisation would therefore improve income growth in poor countries and their convergence towards the income per capita of rich nations. Rodriguez and Rodrik (2000), however, argue that these studies are based on weak evidence, proxy trade restrictions through inappropriate variables (such as the openness index and the deviation of domestic from international prices) and omit key factors from the analysis. They conclude that, likely, there is not a clear relation between trade openness and growth. Lately, Dollar and Kraay (2000) have analysed growth performance over 198095 in relation to trade policy. They found that growth in the countries that significantly cut tariff rates or expanded trade volumes was significantly higher than in the nonglobalizers. Since they assigned China and India to the first group, they argue that trade liberalisation triggers also to a decline in between-country inequality. Their paper has, however, been severely criticised for applying suitably arbitrary criteria in the selection of the 'globalizers' and for other methodological problems that bias the final results (Rodrik 2000). When the same test was repeated with an unbiased country selection, there was no evidence that the globalizers grew faster than the other countries. Rodrik (2000) concludes that while trade and growth clearly correlate with each other, both likely depend on the quality of a country's institutions and not on trade liberalisation per se.

Finally, assigning China and India to the globalizers's club is also problematic. Indeed, the acceleration of growth in China and India started well before trade liberalisation was introduced in the early 1990s (ibid.). More generally, it is difficult to attribute the recent growth of China, India, Vietnam and other countries to textbook liberalisation. While these countries adopted some market reforms and increasingly integrated themselves into the world economy, they did so through a highly unorthodox strategy combining export orientation with high tariff and non-tariff protection, public ownership of banking, patent infringements, restrictions on foreign capital flows and a non convertible exchange rate. Furthermore, both income and wage inequality rose markedly in China and to a lesser extent in India in parallel with the growing globalisation of their economy. While export promotion per se generated a favourable impact on equity, it likely entailed the adoption of other policies - such as a regionally unbalanced industrial policy, fiscal decentralisation and a reversal of the rural-urban terms of trade - that generated a strong disequalizing impact.

- domestic and international financial deregulation. Domestic financial sector reform inspired by 'financial de-repression' was one of the first policy changes introduced in developing countries since the mid-1970s. This reform was conducive to private credit expansion, some financial deepening and the creation of bond and stock markets. But it was also often characterised by inadequate bank supervision, a sizeable rise in interest rates and spreads and growing bank failures. The distributive impact of such measures is difficult to capture but the data are suggestive of a negative impact. Indeed, these policy changes, together with the 1982 rise in US interest rates and the IMF policy of demanding large increases in interest rates in crisis countries, fuelled a worldwide rise in real interest rates in the 1980s. In developing economies real rates often rose by 10-15 points and pushed a number of governments into a 'vicious circle' in which the rate rises augmented the cost of debt servicing, which further pushed upward deficits and 
indebtedness. Financial deregulation thus led to an increase in the rate of return on financial assets, a rise in the share of GDP accruing to capital incomes and the redistribution via the budget of labor income to holders of state bonds.

Domestic deregulation was followed in the early 1990s by the liberalisation of cross border movements of foreign direct investments, bank loans and portfolio investments. With rare exceptions, these measures - and particularly the liberalisation of portfolio flows - generated a sharp social impact. This is in part due to the 'disciplining' structural effect such liberalisation has on the domestic policy decisions of governments (especially in the field of taxation and redistribution) and on the demands of organised labour, and partly due to the real appreciation of the exchange rate which shifts resources to the non-tradeable sector and encourages subcontracting and wage cuts in the tradeable sector to preserve profit margins (Taylor 2000). The impact on inequality is also mediated by the tendency of capital account liberalisation to increase the frequency of destabilising financial crises with real effects (Caprio and Klingebiel 1997). Left to themselves, deregulated financial systems cannot perform well owing to problems of incomplete information, markets and contracts, herd behaviour, panics, weak supervsion and speculation on asset prices.

Indeed, such crises have turned out to be costly, in both the short and medium term, as well as disequalizing. Stiglitz (1998) suggests that countries that suffered from banking crises over 1975-94 saw their GDP growth rate decline on average by 1.3 percent over the subsequent five years in relation to countries that did not experience banking crises. Their distributional impact is also negative, particularly in countries with weak labor institutions and social safety nets, as underscored by an analysis by Galbraith and Lu (1999) who found that in Latin America and Asia financial crises raised inequality in 73 and 62 percent of the time while no impact was evident in Finland, Norway and Spain. Diwan (1999) arrives at similar conclusions. On the basis of panel data he finds that the labor share contracts markedly and permanently in the wake of financial crises while in a subsequent paper, he shows that capital account restrictions help maintain the labour share once financial crises occur (Diwan 2000). In an empirical study on Latin America, Behrman et. al. (2000) find that the strongest wage disequalizing component of the overall reform package was precisely the liberalisation of the capital account. The distributive and social effects of such crises are underscored also by the World Bank (2000) that shows that financial liberalisation raises the poverty rate, via a worsening of income distribution, that persists even after returning to full-capacity growth (Table 10). Analyses based on micro data show that the impact on inequality is transmitted via differential employment, wages and price effects that affect the lower deciles of the distribution especially hard. In analyzing the price changes of the 1997 financial crisis in Indonesia, Levinshon et al (1999) found that price increases had been significantly faster for the poor and for rural households. They conclude noting (p.20) that '.. the notion that the very poor are so poor as to be insulated from international shocks is simply wrong. Rather, in the Indonesian case, the very poor appear to be the most vulnerable.'

Table 10. Poverty incidence before, during and after a few major financial crises (percentages)

\begin{tabular}{|c|c|c|c|}
\hline & before & during & after \\
\hline Argentina $(87-90)$ & 25.2 & 47.3 & 33.7 \\
\hline
\end{tabular}




\begin{tabular}{llll} 
Argentina (93-7) & 16.8 & 24.8 & 26.0 \\
Jordan $(86-92)$ & 3.0 & $\ldots$. & 14.9 \\
Mexico $(94-6)$ & 36.0 & $\ldots$ & 43.0 \\
\hline---10
\end{tabular}

Source: World Bank (2000)

- Domestic policy changes accompanying globalisation. As noted at the beginning of this paper, globalisation tends to be preceded by domestic policy changes that regardless of their inherent merit - render a country more attractive to foreign investors. For instance, in a world of immobile labor and mobile capital, labour markets are liberalised by relaxing the norms on workers dismissal, safety at work, minimum wages, social security contributions, unionisation and collective bargaining either in the whole country or in selected export processing zones. Likewise, policies on corporate taxation, infrastructural development and privatisation may be influenced by the desire to attract foreign investors seeking low-wage, low-tax locations endowed with adequate physical facilities. The distributive impact of these 'complementary policies', however, is seldom factored in the assessment of the impact of open-door policies. While space limitations prevent to deal adequately with this issue, some of the possible linkages are briefly referred to hereafter to illustrate the indirect distributive impact of globalisation.

The liberalisation of the labour market, for instance, is likely to generate a rise in both employment and wage dispersion. The net distributive effect depends on the relative significance of the 'wage inequality effect' and 'employment-creation effect' as well as on the evolving importance of the informal sector. Outside East Asia and China, the experience of last twenty years points to a dominance of the negative effects over the favorable ones. For instance, as noted in section 4.1, it points to slow employment creation, a surge in the share of informal employment, an almost invariable erosion of minimum wages in real terms and relative to the average wage $\frac{14}{\text { and slow employment }}$ creation.

Tax reforms to attract foreign investors may also have had a disequalizing impact. During the last two decades, tax systems moved away from taxes on corporations and trade and towards indirect taxes. In addition, the progressivity of wealth and direct tax rates was reduced though greater accent was placed on horizontal equity by eliminating exemptions and improving collection. The net impact of these reforms has varied from country to country but the general trend is towards lower tax progressivity. In reviewing the impact of tax changes in Latin America, for instance, Morley (2000) notes that the effect of these changes were to shift the burden of taxation away from the wealthy and towards the middle and lower classes.

Finally, privatisation-for-liberalisation, most common in Latin America and Eastern Europe, has a had mixed distributive impact. Privatisation of agriculture has often

\footnotetext{
${ }^{14}$ In the mid 1990s the real minimum wage in Kenya, Uganda and Zimbabwe was 60 percent of the early 1980s level, while in Latin America the minimum wage either declined in relation to its 1980s level with the exception of Colombia, Costarica e Chile (van der Hoeven 2000) and the Eastern European economies in transition Cornia (1996). Similar evidence is available about the rate of unionisation, which has dropped frequently during the era of liberalisation and deregulation.
} 
generated a distributionally favourable impact, as in the case of the dismembering of the communes land in China and of state farms in Armenia and Romania. Privatisation of large industrial assets proved more complex and inequality often rose as institutional reforms in the field of anti-monopoly legislation, competition policy and regulation of privatised utilities and foreign investments has lagged behind. The worst outcomes were observed in the economies in transition where insider privatisation led to rapid concentration of assets in the hands of a small élite of former managers of state enterprises. In Latin America, the acquisition of privatised utilities by multinational firms worsened equity through the low price paid for the assets purchased, the high service prices charged by the privatised utilities, the employment cuts following restructuring and the limited capacity of local regulators to control large transitional corporations. Morley (2000) suggests that privatisation of utilities in Latin America hurt mainly the middle class.

\section{CONCLUSIONS}

Today's globalisation shares several commonalities with that of 1870-1914 but also differs substantially from it (Table 11). While a strongly asymmetric expansion of trade and capital flows characterised both periods, international migration plaid a key role in equalising wages and incomes during the first globalisation but not during the recent one due to the growing restrictions of migration policies in developed countries. Conversely, technology appears to have had a greater impact during the current globalisation than last century. Finally, the impact of current capital flows to emerging and developing countries - dominated by highly unstable and disequalizing portfolio flows - appears to be far more pronounced now than during the first globalisation.

Global inequality appears to have continued growing during the last two decades, though less rapidly than over 1870-1914. The recent rise in globalisation is the result of mutually offsetting trends. On the one side, unprecedented fast growth in Coastal China (and few other East Asian nations) in relation to that of the OECD countries led to a reduction in global inequality, especially in the 1980s. On the other, faster growth in Coastal China and the OECD (the new core of the world economic system) in relation to rural China, rural India and Sub Saharan Africa raised global inequality. Finally, the slow growth or outright stagnation of Eastern Europe, Latin America and MENA relative to the OECD countries also contributed to global inequality, though the comparatively limited populations of these regions moderated this impact.

As during 1870-1914, the current liberalisation and globalisation have led to a selective and asymmetric integration of only a few countries into the core of the world economic system. However - now as then - the majority of the developing and transitional countries has been almost totally bypassed by global integration - despite a considerable opening up of their economies. While over 1870-1914 integration into the world economic core concerned only the nations of the European periphery, the current globalisation has coopted into the core of the world economy most of South East Asia, Coastal China and, possibly, a segment of urban India. Interestingly, the graduation of these economies into the core of the world system was generally guided by 'home grown strategies' combining elements of market reforms with pragmatic and highly unorthodox policies in the fields of trade, finance, patents and exchange rate. 
The reasons why large swathes of the developing and transitional world were bypassed by both globalisations remain unclear but cannot only be attributed - as sometimes argued in the literature - to insufficient commitment to liberalisation. As shown in section 4.1, for instance, Africa has substantially reformed its macroeconomy and trade policy during the last twenty years but has was simultaneously bypassed more than before by international trade and financial flows. Weak domestic conditions in infrastructure, human capital and institutions, as well systemic problems of fallacy of composition, inadequate access to markets and persistent protectionism of the low tech sectors by the advanced countries are other important factors explaining why some regions lag behind despite profound policy reform.

Unlike during the first globalisation wave - when inequality rose in the labour importing New World but fell in the Old World countries exporting labour and manufactured products - the last two decades have witnessed a widespread and symmetric rise in within-country inequality that has involved also the exporters of labour-intensive goods (Table 9). There are three possible explanations for this. First, contrary to the experience of the first globalisation, limited migration to the advanced nations - the main source of convergence last century - did not help equalising the distribution of income in the countries of origin. Second, international financial flows have become less stable and more disequalizing than a century ago. And third, inequality was also influenced in a non-negligible way by domestic policy reforms - such as those of the labour market, financial sector, tax reform - which may have been introduced to facilitate the international integration of poor countries but which had unfavorable effects on the labour share and wage differentials.

Finally, the predictions of standard theory about the inequality impact of international trade and capital flows explained more easily the changes observed during the globalisation of last century than during the last twenty years. Indeed, most of the recent evidence on the inequality impact of globalisation contradicts the predictions of standard theory which is unable to capture the effect of other factors such as domestic institutional weaknesses, the complexity of trade and finance in a multi-country multigoods environment, persistent and rising protectionism in the North and the equity impact of other domestic reforms that are often introduced to facilitate the drive towards globalisation.

Table 11. Summary of the main inequality changes in the global economy, as well as in the Old Core, New Core and the Rest of the world during the globalisation of 18701914 and of $1980-2000$

\begin{tabular}{|l|c|c|}
\hline & $\begin{array}{c}\text { Globalisation wave } \\
1870-1914\end{array}$ & $\begin{array}{c}\text { Globalisation wave } \\
1980-2000\end{array}$ \\
\hline $\begin{array}{l}\text { Integration into world economy } \\
\text { - included in New Core }\end{array}$ & $\begin{array}{l}\text { N.America,N+S.Europe } \\
\text { Argentina, Australia }\end{array}$ & $\begin{array}{l}\text { East Asia, coastal China } \\
\text { Parts of urban India }\end{array}$ \\
- excluded & Rest of the world & Rest of the world \\
\hline $\begin{array}{l}\text { Factors of income convergence } \\
\text { between Old Core and New Core } \\
\text { - trade }\end{array}$ & Important \\
- migration & Dominant & $\begin{array}{c}\text { Dominant } \\
\text { Negligible }\end{array}$ \\
\hline
\end{tabular}




\begin{tabular}{|c|c|c|}
\hline $\begin{array}{l}\text { - capital flows } \\
\text { long term (FDI, Bank lending) } \\
\text { short term (portfolio flows) } \\
\text { - technology }\end{array}$ & $\begin{array}{c}\text { Negative } \\
\text { Negative } \\
\ldots \ldots . . \\
\text { Negligible }\end{array}$ & $\begin{array}{l}\text { Positive-Undetermined } \\
\text { Positive } \\
\text { Negative } \\
\text { Important } \\
\end{array}$ \\
\hline \multicolumn{3}{|l|}{ Income inequality } \\
\hline - global & Rising & Rising slowly \\
\hline - between countries & Rising & Rising \\
\hline$\overline{\text { Old Core vs. New Core }}$ & Falling & Falling \\
\hline $\begin{array}{l}\text { Old Core }+ \text { New Core vs. others } \\
\text { - within countries }\end{array}$ & Rising fast & Rising fast \\
\hline Old Core & Declining & Rising \\
\hline New Core & Rising & Rising \\
\hline Rest of the World & Unknown & Rising \\
\hline $\begin{array}{l}\text { Factors explaining inequality } \\
\text { - External policies } \\
\text {-Domestic policies }\end{array}$ & $\begin{array}{l}\text { Dominant } \\
\text { Unknown }\end{array}$ & $\begin{array}{l}\text { Dominant } \\
\text { Important }\end{array}$ \\
\hline
\end{tabular}

Source: author compilation. 


\section{References}

Altimir, Oscar (1996), "Economic Development and Social Equity", Journal of Interamerican Studies and World Affairs, Summer/Fall 1996.

Anderson, Edward (1999), 'Globalisation and Inequality in Historical Perspective', background paper to the Human Development Report 1999, UNDP, New York.

Barro, Robert (1991), 'Economic growth in a cross section of countries', Quarterly Journal of Economics, 106: 407-443.

Behrman, Jere, Nancy Birdsall and Miguel Székely (2000) "Economic Reform, and Wage Differentials in Latin America", Working Paper of the Research Department n. 435, Inter-American Development Bank, Washington, D.C.

Bigsten, Arne (2000), "Globalisation and Income Inequality in Uganda', paper presented at the Conference on Poverty and Inequality in Developing Countries: A Policy Dialogue on the Effects of Globalisation, 30 November- 1 December 2000, OECD Development Centre, Paris.

Bourguignon, Francois and Christian Morisson (1989), "Income Distribution, Development and Foreign Trade", European Economic Review, 34 (1990).

Bourguignon, Francois and Christian Morisson (2001), "Inequality among World Citizens" (final version, November 2001), mimeo. The World Bank, Washington.

Caprio, Gerard and Daniela Klingebiel (1996), "Bank Insolvencies: Cross-Country Experience", World Bank Policy Research Working Papers 1620, Washington, DC: World Bank.

Chen, Shaohua, Gaurav Datt and Martin Ravallion (1994), 'Is Poverty Increasing in the Developing World?', Review of Income and Wealth, vol.40, No.4, December, pp. 359-376.

Christiaensen, Luc, Lionel Demery and Stefano Paternostro (2002), 'Growth, Distribution and Poverty in Africa: Messages from the 1990s', mimeo, World Bank, Washington, D.C.

Cornia, Giovanni Andrea (1994), " Poverty in Latin America in the Eighties: Extent, Causes and Possible Remedies', Giornale degli Economisti e Annali di Economia, July- September 1994.

Cornia, Giovanni Andrea (1996), "Transition and Income Distribution: Theory, Evidence and Initial Interpretation", WIDER Research in Progress, No.1, UNU/WIDER, Helsinki.

Cornia, Giovanni Andrea with Sampsa Kiiski (2001) "Trends in Income Distribution in the Post World War II Period: Evidence and Interpretation", UNU/WIDER Discussion Papers, UNU/WIDER, Helsinki, Finland.

Diwan, Ishac (1999) "Labour Shares and Financial Crises". Preliminary draft. The World Bank, Washington, D.C.

Diwan, Ishac (2000) "Labour Shares and Globalisation". paper presented at the Conference on Poverty and Inequality in Developing Countries: A Policy Dialogue on the Effects of Globalisation, 30 November- 1 December 2000, OECD Development Centre, Paris.

Dollar, David and Art Kraij (2000), 'Trade, Growth and Poverty', The World Bank

Dowrick, Steve and Muhammad Akmal (2001), 'Contradictory Trends in Global Income Inequality: a Tale of Two Biases', http://ecocomm.anu.edu.au/economics/staff/dowrick/worl-ineq.pdf 
Easterly, William (2001), "The Effect of IMF and World Bank Programs on Poverty", paper prepared for the WIDER Development Conference 'Growth and Poverty' 25-26 May 2001, Helsinki.

Eastwood, Robert and Michael Lipton (2001), "Rural-Urban Dimension of Inequality Change", UNU/WIDER Working Papers, No. 200, UNU/WIDER, Helsinki, Finland.

Feridhanusetyawan, Tubagus (2000), "Globalisation, Poverty and Equity in Indonesia", paper presented at the Conference on Poverty and Inequality in Developing Countries: A Policy Dialogue on the Effects of Globalisation, 30 November- 1 December 2000, OECD Development Centre, Paris.

Fields, Gary and Gyengjoon Yoo (2000), "Falling Labour Income Inequality in Koreas's Economic Growth: Patterns and Underlying Causes', Review of Income and Wealth, Series 46, number 2, June

Fiszbein, Ariel and George Psacharopoulos (1995). "Income Inequality Trends in Latin America in the 1980s" in Nora Lustig (ed.) Coping with Austerity: Poverty and Inequality in Latin America. Brookings Institution, Washington D.C., pages71-100.

Galbraith James and Lu Jiaqing (1999), "Inequality and Financial Crises: Some early Findings" UTIP Working Paper Number 9, LBJ School of Public Affairs, The University of Texas at Austin

Gustafsson Bjorn and Wei Zhong (2000), "How and Why Has Poverty in China Changed?", processed, forthcoming on China Quarterly

Iglesias, Enrique (1998) "Income Distribution and Sustainable Growth: A Latin American Perspective" in Vito Tanzi and Ke-Young Chu, Income Distribution and High-Quality Growth, The MIT Press, Cambridge Massachussets.

Kayizzi-Mugerwa, Steve (2000), "Globalisation, Growth and Income Inequality: A Review of the African Experience", paper presented at the Conference on Poverty and Inequality in Developing Countries: A Policy Dialogue on the Effects of Globalisation, 30 November- 1 December 2000, OECD Development Centre, Paris.

Korea Labour and Society Institute (KLSI) (2001) 'Overview of current economic conditions', http://klsi.org

Korzeniewick, Roberto and Timothy Moran, (1997), 'World-Economic Trends in the Distribution of Income, 1965-1992', American Journal of Sociology, vol.102: 1000-39

Knowles, James, Ernesto Pernia and Mary Racelis (1999), "Social Consequences of the Financial Crisis in Asia" Economic Staff Paper Number 60, Asian Development Bank, Manila

Jha, Raghbendra (2000) "Reducing Poverty and Inequality in India: Has Liberalisation Helped ?", UNU/WIDER Working Papers, No. 204, UNU/WIDER, Helsinki, Finland.

Levinshon, James, Steven Berry and Jed Friedman (1999), 'Impacts of the Indonesian Economic Crisis: Price Changes and the Poor' mimeo, University of Michigan.

Li, Honhyi, Lyn Squire, and Heng-fu Zou (1998) "Explaining International and Intertemporal Variations in Income Inequality", Economic Journal, Vol. 108 No. 446.

Lindert, Peter and Jeffrey Williamson (2001), "Does Globalisation Make the World More Unequal ?", paper presented at the NBER 'Globalisation in Historical Perspective Conference' in Santa Barbara, California, May 3-6, 2001 
Mc Culloch, Neil, Bob Baulch and Milasoa Cherel-Robson (2000), "Globalisation, Poverty and Inequality in Zambia", paper presented at the Conference on Poverty and Inequality in Developing Countries: A Policy Dialogue on the Effects of Globalisation, 30 November- 1 December 2000, OECD Development Centre, Paris.

Milanovic, Branko (1998), Income, Inequality, and Poverty during the Transition from Planned to Market Economy, The World Bank, Washington D.C.

Milanovic, Branko (2000), "The true world income distribution, 1988 and 1993: First calculations based on household surveys alone", mimeo (November 2000), The World Bank, Washington DC.

Morley, Samuel (2000), "Distribution and Growth in Latin America in an Era of Structural Reform", paper presented at the Conference on Poverty and Inequality in Developing Countries: A Policy Dialogue on the Effects of Globalisation, 30 November- 1 December 2000, OECD Development Centre, Paris.

Mundle, Sudipto, and V.B. Tulasidhar (1998), “Adjustment and Distribution: the Indian Experience", Occasional Paper, No. 17. Asian Development Bank, The Philippines.

Murphy, Kevin, Craig Riddell and Paul Romer (1998), 'Wage, Skills and Technology in the United States and Canada' NBER Working Papers No. 6638.

Oshima, Harri (1998), "Income Distribution Policies in East Asia", The Developing Economies, XXXVI-4 (December 1998).

Pangestu, Mary (2000), "Social impact of globalisation is Southeast Asia", paper presented at the Conference on Poverty and Inequality in Developing Countries: A Policy Dialogue on the Effects of Globalisation, 30 November- 1 December 2000, OECD Development Centre, Paris.

Ping, Zhan (1997), "Income Distribution during the Transition in China", UNU/WIDER Working Papers, No. 138, UNU/WIDER, Helsinki, Finland.

Ravallion, Martin, Gaurav Datt and Dominique van der Walle (1991), "Quantifying Absolute Poverty in the Developing World", Review of Income and Wealth, vol. 37, No. 4, December, pp.345-361.

Ravallion, Martin and Shaohua Chen (1997), "What Can New Survey Data Tell Us about Recent Changes in Distribution and Poverty?", World Bank Economic Review, vol.11, No.2, pp.357-82

Ravallion, Martin and Gaurav Datt (1999), "When is growth pro-poor ? Evidence from the diverse experience of Indian states". Mimeo,The World Bank, Washington ,DC.

Rodriguez, Francisco and Dani Rodrik (2000). "Trade Policy and Economic Growth: A Sceptic's Guide to the Cross-National Evidence", in B.Bernanke and K.Rogoff, NBER Macroeconomics Annual 2000, Cambridge, MA, MIT Press, forthcoming.

Rodrik, Dani (1997). Has Globalization Gone Too Far?, Institute for International Economics, Washington, DC..

Rodrik, Dani (2000), “Comments on 'Trade, Growth and Poverty” by D.Dollar, and Art Kraay', mimeo, Harvard University.

Rutkowski, Jan (1999), "Wage Inequality in Transition Economies of Central Europe: Trends and Pattern in the Late 1990s". Mimeo, August 1999.

Sachs, Jeffrey and Andrew Warner (1995), "Natural Resource Abundance and Economic Growth", NBER Working Papers, No. 5398.

Sainz, Pedro and Alfredo Calcagno (1992), "Em Busca de Otra Modalidad de Desarrollo", CEPAL Review, No. 48, December. 
Sala-i-Martin, Xavier (2002), 'The Disturbing 'Rise' of Global Income Inequality', NBER Working Paper Series 8904, National Bureau of Economic Research, Cambridge, MA

Sarntisart, Isra (2000), " Growth, Structural Change and Inequality: the Experience of Thailand", UNU/WIDER Working Paper N. 207, World Institute for Development Economics Research, Helsinki

Schultz, T. Paul (1998), 'Inequality in the distribution of personal income in the world: how it is changing and why', Journal of Population Economics, 1998: 307-344.

Slaughter, Matthew (2000), 'Protectionist Tendencies in the North and Vulnerable Economies in the South' WIDER Working Paper Series, No.196, September, UNU/WIDER, Helsinki.

Stewart, Frances (n.d.), 'Globalisation, Liberalisation and Inequality: Expectations and Experience', mimeo, Queen Elizabeth House, Oxford.

Stiglitz, Joseph (1998) "More Instruments and Broader Goals: Moving toward the PostWashington Consensus", UNU/WIDER Annual Lectures, 2, UNU/WIDER, Helsinki, Finland, (January).

Székely, Miguel and Marianne Hilgert (1999), 'The 1990s in Latin America: Another Decade of Persistent Inequality', Working Paper 410, Research Department of the Inter-American Development Bank, Washington, DC.

Taylor, Lance (2000), "External Liberalisation, Economic Performance and Distribution in Latin America and Elesewhere", UNU/WIDER Working Paper N. 215, World Institute for Development Economics Research, Helsinki

Tokman, Victor (1986), "Ajuste y Empleo: Los Desafios del Presente", PREALC, Regional Employment Programme for Latin America and the Caribbean. Mimeo. Santiago, Chile

UNCTAD (1997), Trade and Development Report", UNCTAD, Geneva, Switzerland.

UNDP (1999), 'Human Development Report', Oxford University Press, Oxford.

UNICEF (1997), 'Regional Monitoring Report' N.5, Unicef-ICDC, Florence

Williamson, Jeffrey (1996), "Globalisation and Inequality then and now: the Late $19^{\text {th }}$ and late $20^{\text {th }}$ Centuries Compared", NBER Working Paper Series N.5491, Cambridge

Wood, Adrian (1994), North-South Trade, Employment and Inequality, Clarendon Press, Oxford, United Kingdom.

World Bank (2000), World Development Report 2000/1. Consultation draft, 17 January 2000, The World Bank, Washington D.C 


\section{CESifo Working Paper Series}

(for full list see www.cesifo.de)

778 Antonio Merlo and François Ortalo-Magné, Bargaining over Residential Real Estate: Evidence from England, September 2002

$779 \mathrm{Yu}-\mathrm{Fu}$ Chen and Michael Funke, Exchange Rate Uncertainty and Labour Market Adjustment under Fixed and Flexible Exchange Rates, September 2002

780 Michael S. Michael, International Migration, Income Taxes and Transfers: A Welfare Analysis, September 2002

781 Clemens Fuest and Alfons Weichenrieder, Tax Competition and Profit Shifting: On the Relationship between Personal and Corporate Tax Rates, October 2002

782 Jan Bouckaert and Hans Degryse, Softening Competition by Enhancing Entry: An Example from the Banking Industry, October 2002

783 Johann K. Brunner and Susanne Pech, Adverse Selection in the Annuity Market with Sequential and Simultaneous Insurance Demand, October 2002

784 Gregory D. Hess and Eduard Pelz, The Economic Welfare Cost of Conflict: An Empirical Assessment, October 2002

785 Jan Erik Askildsen, Uwe Jirjahn, and Stephen C. Smith, Works Councils and Environmental Investment: Theory and Evidence from German Panel Data, October 2002

786 Geir H. Bjønnes, Dagfinn Rime, and Haakon O. Aa. Solheim, Volume and Volatility in the FX-Market: Does it matter who you are?, October 2002

787 John Evans and John Fingleton, Entry Regulation and the Influence of an Incumbent Special Interest Group, October 2002

788 Wolfgang Ochel, International Comparisons and Transfer of Labour Market Institutions, October 2002

789 B. Gabriela Mundaca, Moral Hazard Effects of Bailing out under Asymmetric Information, October 2002

790 Gene M. Grossman and Edwin L.-C. Lai, International Protection of Intellectual Property, October 2002

791 John Hassler, José V. Rodriguez Mora, Kjetil Storesletten, and Fabrizio Zilibotti, A Positive Theory of Geographic Mobility and Social Insurance, October 2002

792 Paul De Grauwe and Marianna Grimaldi, The Exchange Rate in a Model with Heterogeneous Agents and Transactions Costs, October 2002 
793 Guido Friebel and Mariassunta Giannetti, Fighting for Talent: Risk-shifting, Corporate Volatility, and Organizational Change, October 2002

794 Jan Erik Askildsen, Badi H. Baltagi, and Tor Helge Holmås, Will Increased Wages Reduce Shortage of Nurses? A Panel Data Analysis of Nurses' Labour Supply, October 2002

795 Marko Köthenbürger and Panu Poutvaara, Social Security Reform and Intergenerational Trade: Is there Scope for a Pareto-Improvement?, October 2002

796 Paul De Grauwe and Laura Rinaldi, A Model of the Card Payment System and the Interchange Fee, October 2002

797 Volker Böhm and Tomoo Kikuchi, Dynamics of Endogenous Business Cycles and Exchange Rate Volatility, October 2002

798 Mariam Camarero, Javier Ordóñez, and Cecilio Tamarit, The Euro-Dollar Exchange Rate: Is it Fundamental?, October 2002

799 Misa Tanaka, How Do Bank Capital and Capital Adequacy Regulation Affect the Monetary Transmission Mechanism?, October 2002

800 Jörg Baten and Andrea Wagner, Autarchy, Market Disintegration, and Health: The Mortality and Nutritional Crisis in Nazi Germany, 1933-1937, October 2002

801 Saku Aura, Uncommitted Couples: Some Efficiency and Policy Implications of Marital Bargaining, October 2002

802 Wolfram F. Richter, Delaying Integration of Immigrant Labor for the Purpose of Taxation, October 2002

803 Gil S. Epstein and Shmuel Nitzan, The Politics of Randomness, October 2002

804 John Hassler and José V. Rodriguez Mora, Should UI Benefits Really Fall over Time?, October 2002

805 Friedrich Breyer and Stefan Felder, The Dead-anyway Effect Revis(it)ed, October 2002

806 Assar Lindbeck and Solveig Wikström, E-exchange and the Boundary between Households and Organizations, November 2002

807 Dieter Bös, Contests Among Bureaucrats, November 2002

808 Steven Brakman, Harry Garretsen, and Marc Schramm, The Strategic Bombing of German Cities during World War II and its Impact on City Growth, November 2002

809 Florian Englmaier and Achim Wambach, Contracts and Inequity Aversion, November 2002 
810 Sarbajit Sengupta, Delegating Recruitment under Asymmetric Information, December 2002

811 Rajshri Jayaraman, On the Partial Public Provision of a Private Good, December 2002

812 Stéphanie Stolz, Banking Supervision in Integrated Financial Markets: Implications for the EU, December 2002

813 Christian Keuschnigg, Taxation of a Venture Capitalist with a Portfolio of Firms, December 2002

814 Inés Macho-Stadler and David Pérez-Castrillo, Settlement in Tax Evasion Prosecution, December 2002

815 Rainer Niemann and Dirk Simons, Costs, Benefits, and Tax-induced Distortions of Stock Option Plans, December 2002

816 Jan-Egbert Sturm and Barry Williams, Deregulation, Entry of Foreign Banks and Bank Efficiency in Australia, December 2002

817 V. Anton Muscatelli, Patrizio Tirelli, and Carmine Trecroci, Monetary and Fiscal Policy Interactions over the Cycle: Some Empirical Evidence, December 2002

818 Claude Hillinger, A General Theory of Price and Quantity Aggregation and Welfare Measurement, December 2002

819 Erkki Koskela and Ronnie Schöb, Optimal Capital Taxation in Economies with Unionised and Competitive Labour Markets, December 2002

820 Sheilagh Ogilvie, Guilds, Efficiency, and Social Capital: Evidence from German ProtoIndustry, December 2002

821 Hans Gersbach and Verena Liessem, Financing Democracy, December 2002

822 Costas Hadjiyiannis, Panos Hatzipanayotou, and Michael S. Michael, Optimal Tax Policies with Private-Public Clean-Up, Cross-Border Pollution and Capital Mobility, December 2002

823 François Ortalo-Magné and Sven Rady, Homeownership: Low Household Mobility, Volatile Housing Prices, High Income Dispersion, December 2002

824 Syed M. Ahsan and Panagiotis Tsigaris, Measuring the Social Discount Rate under Uncertainty: A Methodology and Application, December 2002

825 Kai A. Konrad, Altruism and Envy in Contests: An Evolutionarily Stable Symbiosis, December 2002

826 Robert S. Chirinko and Huntley Schaller, A Revealed Preference Approach to Understanding Corporate Governance Problems: Evidence from Canada, December 2002 
827 Geir B. Asheim, Green National Accounting for Welfare and Sustainability: A Taxonomy of Assumptions and Results, December 2002

828 Andrea Gebauer, Chang Woon Nam, and Rüdiger Parsche, Lessons of the 1999 Abolition of Intra-EU Duty Free Sales for Eastern European EU Candidates, December 2002

829 Giacomo Corneo, Work and Television, December 2002

830 Vivek H. Dehejia and Yiagadeesen Samy, Trade and Labour Standards - Theory, New Empirical Evidence, and Policy Implications, December 2002

831 Geir B. Asheim and Wolfgang Buchholz, A General Approach to Welfare Measurement through National Income Accounting, December 2002

832 Aaron Tornell and Frank Westermann, The Credit Channel in Middle Income Countries, January 2003

833 Gebhard Flaig, Time Series Properties of the German Monthly Production Index, January 2003

834 Campbell Leith and Jim Malley, Estimated Open Economy New Keynesian Phillips Curves for the G7, January 2003

835 Burkhard Heer and Bernd Süssmuth, Inflation and Wealth Distribution, January 2003

836 Erkki Koskela and Leopold von Thadden, Optimal Factor Taxation under Wage Bargaining - A Dynamic Perspective, January 2003

837 Carola Grün and Stephan Klasen, Growth, Income Distribution, and Well-Being: Comparisons across Space and Time, January 2003

838 Robert S. Chirinko and Ulf von Kalckreuth, On the German Monetary Transmission Mechanism: Interest Rate and Credit Channels for Investment Spending, January 2003

839 Sascha O. Becker, Andrea Ichino, and Giovanni Peri, How Large is the "Brain Drain" from Italy?", January 2003

840 Albert Berry and John Serieux, All About the Giants: Probing the Influences on Growth and Income Inequality at the End of the $20^{\text {th }}$ Century, January 2003

841 Robert Fenge and Martin Werding, Ageing and the Tax Implied in Public Pension Schemes: Simulations for Selected OECD Countries, January 2003

842 Robert Fenge and Martin Werding, Ageing and Fiscal Imbalances Across Generations: Concepts of Measurement, January 2003

843 Giovanni Andrea Cornia, The Impact of Liberalisation and Globalisation on Income Inequality in Developing and Transitional Economies, January 2003 